\title{
Recently Developed Adsorbing Materials for Fluoride Removal from Water and Fluoride Analytical Determination Techniques: A Review
}

\author{
Athanasia K. Tolkou ${ }^{1}(\mathbb{D})$, Natalia Manousi ${ }^{2}(\mathbb{D})$, George A. Zachariadis ${ }^{2}$ (D), Ioannis A. Katsoyiannis ${ }^{1, *}$ \\ and Eleni A. Deliyanni ${ }^{1, * \mathbb{D}}$ \\ 1 Laboratory of Chemical and Environmental Technology, Department of Chemistry, Aristotle University of \\ Thessaloniki, 54124 Thessaloniki, Greece; tolkatha@chem.auth.gr \\ 2 Laboratory of Analytical Chemistry, Department of Chemistry, Aristotle University of Thessaloniki, \\ 54124 Thessaloniki, Greece; nmanousi@chem.auth.gr (N.M.); zacharia@chem.auth.gr (G.A.Z.) \\ * Correspondence: katsogia@chem.auth.gr (I.A.K.); lenadj@chem.auth.gr (E.A.D.)
}

Citation: Tolkou, A.K.; Manousi, N.; Zachariadis, G.A.; Katsoyiannis, I.A.; Deliyanni, E.A. Recently Developed Adsorbing Materials for Fluoride Removal from Water and Fluoride Analytical Determination Techniques: A Review. Sustainability 2021, 13, 7061 https://doi.org/10.3390/su13137061

Academic Editors: Jose Navarro Pedreño, António Dinis Ferreira, Peter Goethals, Eun-Sung Chung and Vincenzo Torretta

Received: 5 June 2021

Accepted: 21 June 2021

Published: 23 June 2021

Publisher's Note: MDPI stays neutral with regard to jurisdictional claims in published maps and institutional affiliations.

Copyright: (c) 2021 by the authors. Licensee MDPI, Basel, Switzerland. This article is an open access article distributed under the terms and conditions of the Creative Commons Attribution (CC BY) license (https:// creativecommons.org/licenses/by/ $4.0 /)$.

\begin{abstract}
In recent years, there has been an increase in public perception of the detrimental sideeffects of fluoride to human health due to its effects on teeth and bones. Today, there is a plethora of techniques available for the removal of fluoride from drinking water. Among them, adsorption is a very prospective method because of its handy operation, cost efficiency, and high selectivity. Along with efforts to assist fluoride removal from drinking waters, extensive attention has been also paid to the accurate measurement of fluoride in water. Currently, the analytical methods that are used for fluoride determination can be classified into chromatographic methods (e.g., ionic chromatography), electrochemical methods (e.g., voltammetry, potentiometry, and polarography), spectroscopic methods (e.g., molecular absorption spectrometry), microfluidic analysis (e.g., flow injection analysis and sequential injection analysis), titration, and sensors. In this review article, we discuss the available techniques and the ongoing effort for achieving enhanced fluoride removal by applying novel adsorbents such as carbon-based materials (i.e., activated carbon, graphene oxide, and carbon nanotubes) and nanostructured materials, combining metals and their oxides or hydroxides as well as natural materials. Emphasis has been given to the use of lanthanum ( $\mathrm{La}$ ) in the modification of materials, both activated carbon and hybrid materials (i.e., $\mathrm{La} / \mathrm{Mg} / \mathrm{Si}-\mathrm{AC}, \mathrm{La} / \mathrm{MA}, \mathrm{LaFeO}_{3} \mathrm{NPs}$ ), and in the use of $\mathrm{MgO}$ nanostructures, which are found to exhibit an adsorption capacity of up to $29,131 \mathrm{mg} \mathrm{g}^{-1}$. The existing analytical methodologies and the current trends in analytical chemistry for fluoride determination in drinking water are also discussed.
\end{abstract}

Keywords: activated carbon; adsorbents; fluoride; graphene oxide; colorimetric sensors; fluorescence sensors

\section{Introduction}

Fluoride ions are the negatively charged species of fluorine that occur in a plethora of minerals which can be present both in water and soil. Although there have been some reports of the possible beneficial effects of low concentrations of fluoride on dental health, especially when considered as an effective means of preventing dental caries [1], the exposure to excessive fluoride concentrations can cause severe damages to human health [1]. The negative effects of extensive fluoride exposure include dental and skeletal fluorosis, endocrine effects, attention deficit hyperactivity disorder, and neurotoxicity [2]. The margin between the desired and the undesired fluoride dose is narrow and there is therefore a great need to supervise and evaluate the quality of drinking water and, when necessary, to remove the excess of fluoride from water in order to protect human health $[1,3]$. Table 1 summarizes the acceptable concentration values of fluoride in drinking water and the health effects associated with those concentration levels. 
Table 1. Fluoride health effect associated with concentration levels and permissible limits of fluoride in drinking water according to the International Standards organization $[4,5]$.

\begin{tabular}{|c|c|c|c|}
\hline $\begin{array}{l}\text { Fluoride Concentration } \\
\qquad\left(\mathrm{mg} \mathrm{L}^{-1}\right)\end{array}$ & Effects & $\begin{array}{c}\text { International Standards } \\
\text { Organization }\end{array}$ & $\begin{array}{l}\text { Permissible Limit } \\
\quad\left(\mathrm{mg} \mathrm{L}^{-1}\right)\end{array}$ \\
\hline$<0.5$ & Prevention of teeth cavities & World Health Organization (WHO) & $0.6-1.5$ \\
\hline $0.5-1.5$ & $\begin{array}{l}\text { Helps in bones and teeth } \\
\text { development }\end{array}$ & Bureau of Indian Standards (BIS) & $0.6-1.5$ \\
\hline $1.5-4$ & Dental problems in children & US Public Health Standards & 0.8 \\
\hline$>4$ & $\begin{array}{l}\text { Dental and skeleton } \\
\text { fluorosis }\end{array}$ & $\begin{array}{l}\text { Indian Council of Medical } \\
\text { Research (ICMR) }\end{array}$ & 1.0 \\
\hline$>10$ & $\begin{array}{l}\text { Crippling skeletal fluorosis, } \\
\text { possibly cancer }\end{array}$ & Directive 98/83/EC & 1.5 \\
\hline
\end{tabular}

Although groundwater comprises a safe drinking water source for billions of people [6], there are some cases where groundwater presents unacceptable contamination levels and cannot be used without treatment for potable purposes. The fluoride contamination of drinking water is an environmental issue concerning a big part of the global population. In particular, in countries such as India, Bangladesh, China, Pakistan, Ghana, and Tanzania $[7,8]$, the concentrations of fluoride in the waters are so high that several thousands of people suffer from fluoride associated illnesses. Effective fluoride removal in these regions is thought to be a difficult and stimulating matter, mainly due to the difficulties arising from fluoride chemistry which prevent fluoride from being efficiently sorbed by most conventional adsorbents used in the drinking water industry. A lack of essential infrastructure and technological know-how also play a significant part. [7,9]. However, China [10] and India [11] are making efforts to defeat this problem and the situation is constantly improving.

Consequently, fluoride removal from drinking water has received great attention in the last years and several technologies have been tested in laboratories or applied in the field [12-15]. Ion exchange, chemical precipitation, membrane processes, coagulation, adsorption and both phyto and bio-remediation are the main technologies which have already applied for the removal of fluoride in potable water treatment. Figure 1 summarizes the commonly applied techniques and their main advantages and disadvantages.

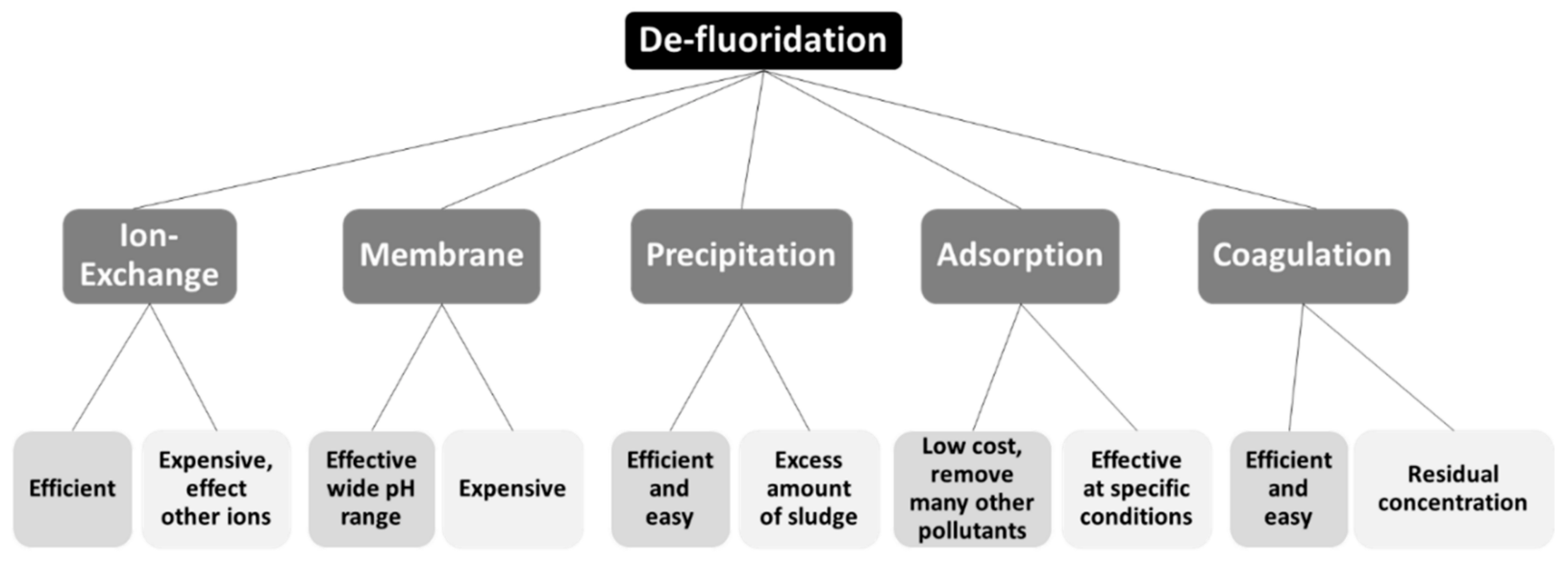

Figure 1. Commonly applied techniques for fluoride removal from drinking water [16-19].

Nevertheless, most of the aforementioned methods display particular disadvantages. In the case of ion-exchange, the price of resin, its regeneration and resultant waste disposal requirements, and the fact that it is not selective enough preclude this method from be- 
ing efficient and cost-effective [18]. The use of membranes belongs to the same category of disadvantages, as the elevated cost of membrane acquisition and operation and the disposal of concentrates, which necessitates posttreatment of water, makes the process rather uneconomical [20]. Coagulation, on the other hand, is an economical technology for defluoridation but requires high doses, leading in high residual concentrations, (e.g., of harmful aluminum) and hence produces significant amounts of sludge [17]. Precipitation methods relying on the use of calcium, aluminum, and iron salts have been widely published in the literature as well. Nevertheless, the problems related to lime-based processes include the low solubility of the resulting calciumhydroxide, which hinders adequate removal of fluoride from the waters $[17,18]$. Among these processes, adsorption is a very promising technique due to its handy operation, low-cost operation, increased selectivity, and the readiness of adsorbents. Materials such as alumina [16], activated carbon [21], ion exchange resins [22], silica gel [23], natural materials such as clay [24] and mud [25,26], and low-cost alternative adsorbents such as fly ash [27,28], bone charcoal [29], metallic iron [30], nanomaterials [31,32], etc., have been employed [12-14].

In parallel, due to its profound effect on human teeth and bones, there is a demand for the development of precise and sensitive analytical methods for the measurement of fluoride in aquatic solutions. Until recently, several methods have been developed to determine fluoride in drinking water. These methods were classified into six main categories [33], namely chromatographic, electrochemical and spectroscopic methods, microfluidic analysis, titration, and sensors. Among the chromatographic methods, high-performance liquid chromatography (HPLC), ion chromatography (IC), and gas chromatography (GC) are the most widely used techniques for fluoride determination. Electrochemical methods include potentiometry, ion selective potentiometry, polarography, and voltammetry. Spectroscopic methods include atomic and molecular spectroscopy, while microfluidic analysis includes flow injection analysis (FIA) and sequential injection analysis (SIA) [33,34]. Up to date, the development of novel cost-efficient fluoride monitoring systems for the assessment of drinking water quality has been undoubtedly at the forefront of research [33,35].

There is a number of review articles in the literature regarding the removal $[3,36,37]$ and the analytical determination $[33,36]$ of fluoride from various matrices. Herein, the methodology that we followed to prepare this review study was based on the presentation and the discussion of recently developed materials (mainly adsorptive materials) in order to highlight the specific properties which enhance fluoride removal. Novel adsorbents have been classified in the following categories: carbon-based materials (i.e., activated carbon $(\mathrm{AC})$, graphene oxide $(\mathrm{GO})$ and carbon nanotubes $(\mathrm{CNTs})$ ); nanostructured materials combining metals and their oxides or hydroxides; and natural materials. These adsorbents have been reviewed and critically assessed. Regarding analytical techniques, the most common techniques for fluoride determination are presented, and an emphasis has been given to methodologies developed between 2015 and 2021. The novelty of this review is based on the fact that the most recent reviews for fluoride removal have only reported, in general, on the technologies used for removal and have not focused on newly produced adsorbing materials. To the best of our knowledge, this is the first review which also combines the relevant analytical techniques required for fast and accurate fluoride determination. The further objective of the present study is to compare and identify possible new materials with high advantages for fluoride removal with the aim of producing an adsorbent with high efficiency for fluoride removal which will also be able to be placed in the market.

\section{Fluoride Removal from Drinking Water by Adsorption}

In this section, the recently developed adsorbing materials for fluoride removal from water are categorized as follows: carbon-based materials (i.e., AC, GO and CNTs) and other nanostructured materials. The following is a description of the basic characteristics of several recently developed materials. In Table 2, these are summarized and their characteristics are compared. 


\subsection{Carbon-Based Adsorbents}

Carbon-based materials have been proved to be very beneficial in the potabilization of water since they demonstrate outstanding adsorption characteristics. Research findings have shown that activated carbon, graphene oxide, and carbon nanotube have plentiful surface functional groups and substantial specific surface areas [37]. The aim of this section is to summarize and assess carbon-based materials for de-fluoridation of water on the basis of their effectiveness, cost-effectiveness, and readiness for application [5].

Currently, one of the most widely applied carbon-based materials for fluoride removal is bone char (BC), which is considered as a conventional treatment [38] with very good reported removal efficiencies [39] and, in some cases, is considered as a green sorbent [40]. Bone char is a material comprised of carbonated and inorganic materials $(70-76 \%$ of hydroxyapatite (HAP, $\left.\left.\mathrm{Ca}_{10}\left(\mathrm{PO}_{4}\right)_{6}(\mathrm{OH})_{2}\right)\right)$ that has been successfully utilized to decrease the content of fluoride in water [41,42]. Several recent studies [29,43-46], have reported very high adsorption capacities (i.e., $11.2 \mathrm{mg} \mathrm{F}^{-} \mathrm{g}^{-1}$ for Chicken Bone Char (CBC)) [45]. However, the use of bone char and its application for de-fluoridation can be hindered by the traditions and religious attitudes of people (i.e., char derived from cow bones is not tolerable by Hindus and, likewise, pig's bone char is not acceptable by Muslims) [40]. In addition, the use of low-grade bone char adds bad taste and odor to the treated water. Moreover, owing to the numerous reviews that already exist specifically for bone char application for the de-fluoridation of waters, bone char is not further examined in detail in this review.

\subsubsection{Activated Carbon}

$\mathrm{AC}$ is a common adsorptive material, used for removing pollutants from water sources due to its enhanced porosity, significant surface area, and also its adaptable surface chemistry [47]. Modified activated carbon materials with the oxides and hydroxides of metals have been used to expand its available surface area [48] and to strengthen its interactions with fluoride [49].

\section{Activated Carbon Fibers Modified with Zirconium (Zr-ACF)}

In the study conducted by Pang et al. [50], a new drop-coating method was created to prepare $\mathrm{Zr}$-ACF adsorbents for fluoride removal. Adsorption trials at $\mathrm{pH}$ values between 3 and 11 showed that ion exchange and electrostatic attraction were the main mechanisms of fluoride retention. The pseudo-second-order model (PSO) describes properly the kinetics of fluoride adsorption, and the Langmuir model $\mathrm{f}$ fitted well to the isotherms data. The highest adsorption capability was $28.50 \mathrm{mg} \mathrm{L}^{-1}$. The thermodynamic study indicated that the adsorption process of fluoride onto $\mathrm{Zr}-\mathrm{ACF}$ is endothermic and spontaneous, as indicated by the negative value of Gibbs energy $\left(\Delta G^{\circ}\right)[51,52]$ and the positive value of enthalpy $\left(\Delta \mathrm{H}^{\circ}\right)$ [53], respectively. The results indicated that $\mathrm{Zr}$-ACF made by drop-coating is a cost-effective and high-capacity adsorbent for fluoride removal due to its simplicity of synthesis and enhanced adsorption capacity.

\section{Activated Carbon of Avocado Seeds (ACAS)}

The study conducted by Tefera et al. [54] investigated the performance of ACAS for fluoride removal from aqueous solutions and groundwaters. Adsorption of fluoride onto ACAS reached its equilibrium condition at the contact time of $60 \mathrm{~min}$ at $\mathrm{pH} 6$ and an ACAS dose of $19 \mathrm{~g} \mathrm{~L}^{-1}$ with a fluoride starting concentration of $5.2 \mathrm{mg} \mathrm{L}^{-1}$. The experimental data were well fitted to the Langmuir isotherm model with a highest adsorption capability of $1.2 \mathrm{mg} \mathrm{g}^{-1}$.

\section{Activated Carbon Derived from $\mathrm{CaCl}_{2}$-Modified Crocus Sativus Leaves (AC-CMCSL)}

Fluoride adsorption by AC-CMCSL [55], at its best conditions (i.e., an influent fluoride concentration of $6.5 \mathrm{mg} \mathrm{L}^{-1}, \mathrm{pH}$ value of 4.5 , adsorbent dose of $15 \mathrm{~g} \mathrm{~L}^{-1}$, and reaction time of $70 \mathrm{~min}$ ) showed a maximum adsorption capacity of $2.01 \mathrm{mg} \mathrm{g}^{-1}$. The results 
fit well with the Langmuir model. In addition, the impact of the co-occurring anions on fluoride sorption was examined, and their effect is reflected in the following order: $\mathrm{PO}_{4}{ }^{3-}>\mathrm{SO}_{4}{ }^{2-}>\mathrm{Cl}^{-}>\mathrm{NO}_{3}{ }^{-}$. The findings of the presented study showed that ACCMCSL has a moderate ability for fluoride removal from waters. The thermodynamic parameters calculated in this study confirmed the endothermic nature of the adsorption on AC-CMCS, indicated by a positive value of $\Delta \mathrm{H}^{\circ}\left(+22.6 \mathrm{~kJ} \mathrm{~mol}^{-1}\right)$ and the fact that the adsorption of fluoride on AC-CMCSL was spontaneous, as all $\Delta \mathrm{G}^{\circ}$ values were negative for all the studied temperatures (i.e., $-0.20576 \mathrm{~kJ} \mathrm{~mol}^{-1}$ at $303 \mathrm{~K}$ ).

\section{$\mathrm{La} / \mathrm{Mg} /$ Si-Activated Carbon}

$\mathrm{La} / \mathrm{Mg} / \mathrm{Si}-\mathrm{AC}$, originating from palm shells, was recently studied and was found to be an appropriate material for eliminating fluoride from natural waters [56]. It is worth noting that $\mathrm{La} / \mathrm{Mg} / \mathrm{Si}-\mathrm{AC}$ has a rough and porous structure, homogeneously modified by impregnation with $\mathrm{La}, \mathrm{Mg}$, and $\mathrm{Si}$. This material was found to be applied to the concurrent removal of aluminum and fluoride from solutions. The adsorption process of fluoride is driven by an endothermic $\left(\Delta \mathrm{H}^{\circ}=+7.5 \times 10^{3} \mathrm{~kJ} \mathrm{~mol}^{-1}\right)$ and spontaneous $\left(\Delta \mathrm{G}^{\circ}=-1.41 \times 10^{4} \mathrm{~kJ} \mathrm{~mol}^{-1}\right.$ at $\left.308 \mathrm{~K}\right)$ reaction and was more favored at acidic $\mathrm{pH}$ values than the point of zero charge of $\mathrm{La} / \mathrm{Mg} / \mathrm{Si}-\mathrm{AC}\left(\mathrm{pH}_{\mathrm{pzc}} 9.6\right)$ with a high temperature.

A schematic presentation of the relative presented activated carbon materials used for fluoride removal is illustrated in Figure 2 showing the modification type, the optimum $\mathrm{pH}$ value for adsorption, the maximum adsorption capacity, and the contact time of adsorption.

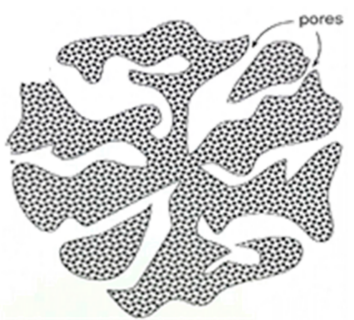

Activated Carbon
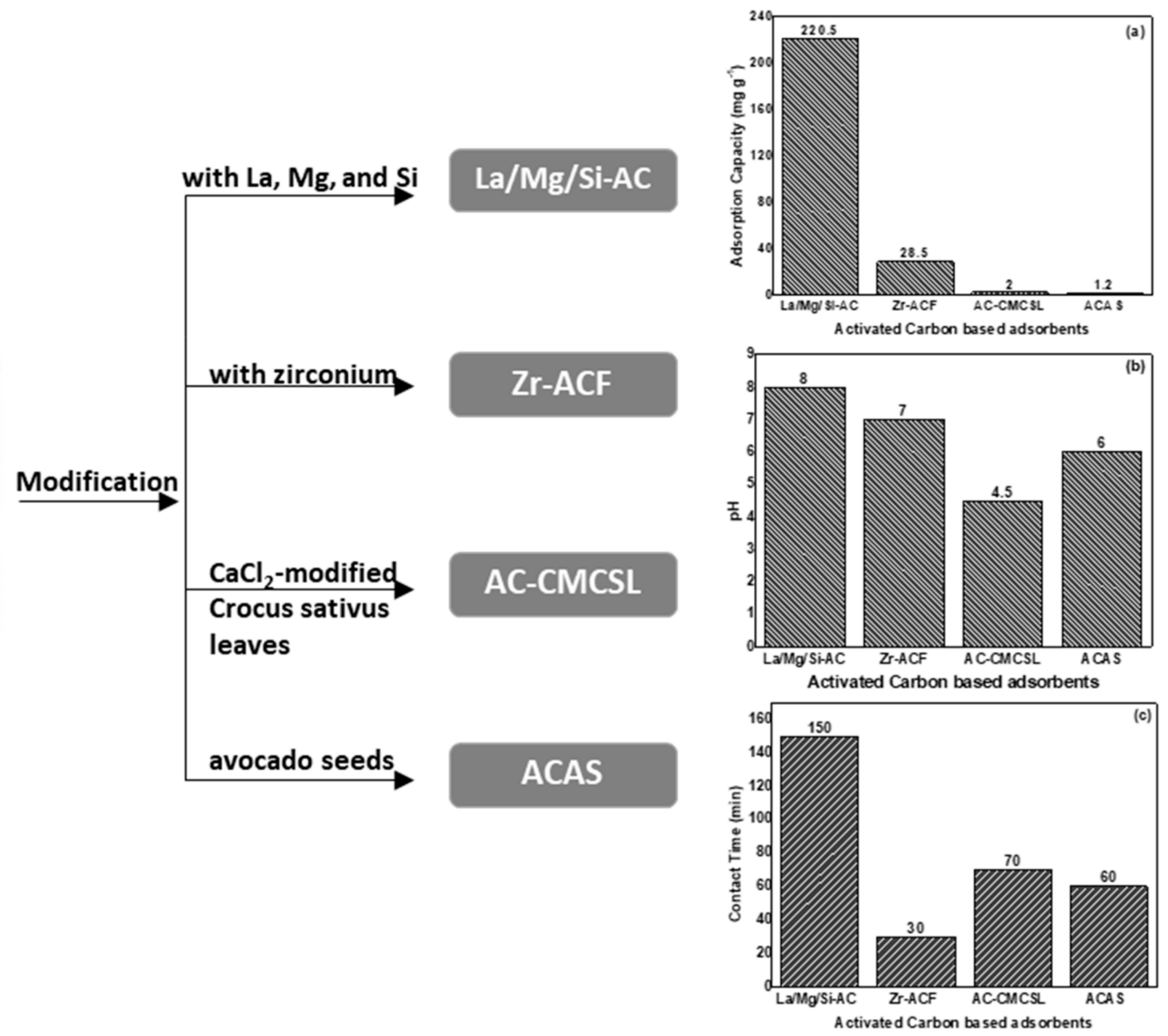

Figure 2. Schematic presentation of modified activated carbon-based materials used for fluoride removal, showing (a) the $\mathrm{pH}$ optimum activity, (b) the maximum adsorption capacity, and (c) the contact time of adsorption. 
In more detail, Figure 3 shows, in descending order, the maximum adsorption capacity $\left(\mathrm{mg} \mathrm{g}^{-1}\right)$ of the modified activated carbon materials presented in this study. As depicted, $\mathrm{La} / \mathrm{Mg} / \mathrm{Si}-\mathrm{AC}$ exhibited the highest capacity (220.5 $\mathrm{mg} \mathrm{g}^{-1}$ ) among them.

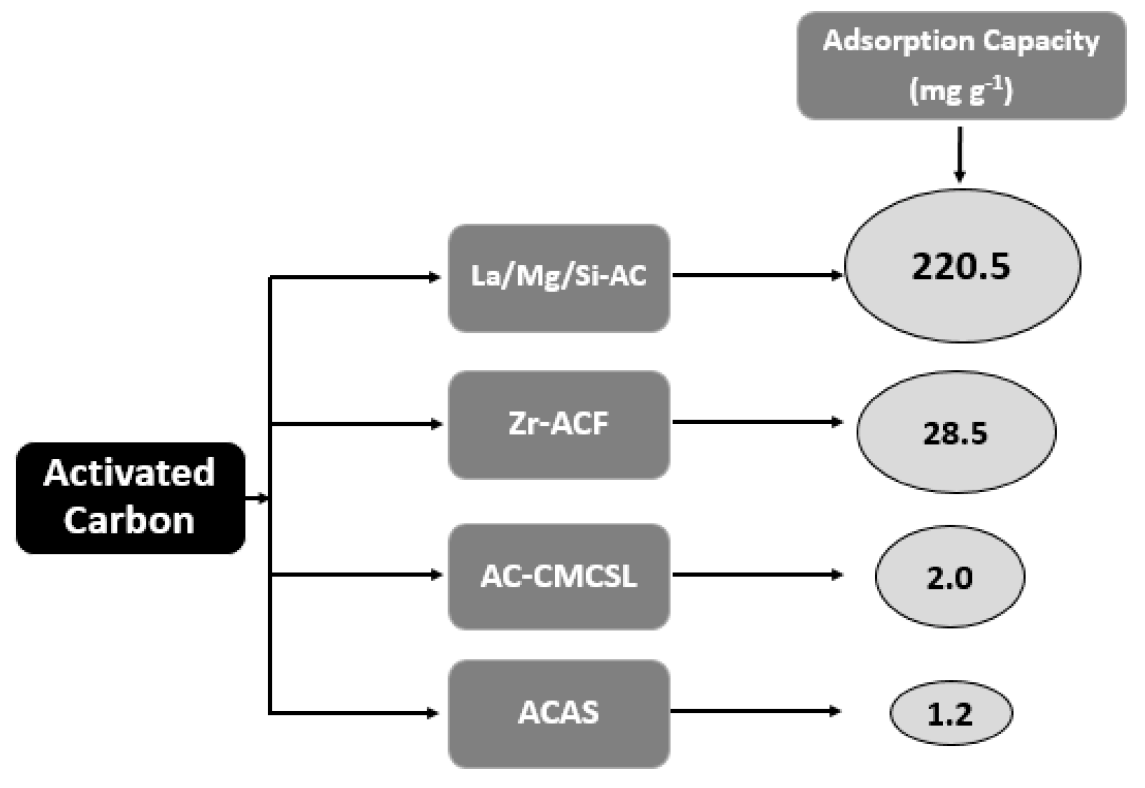

Figure 3. Schematic graph of depicting maximum adsorption capacities $\left(\mathrm{mg} \mathrm{g}^{-1}\right)$ of presented activated carbon-based materials.

\subsubsection{Graphene Oxide}

Recently, GO has been widely effectively applied in water treatment $[57,58]$. However, pure GO materials show inadequate adsorption ability. Besides, they are very slight and stable in water, making them very challenging to recover after adsorption. One efficient way to overcome this challenge is to amend its surface [59]. Considerable research studies in this direction have been dedicated to changing the local reactivity via doping or grafting elements such as $\mathrm{Al}, \mathrm{Mn}, \mathrm{Fe}, \mathrm{Mg}, \mathrm{Au}, \mathrm{Ti}, \mathrm{B}$, and Si [60,61] among others.

\section{Graphene Oxide/Alumina Nano-Composite}

$\mathrm{GO} / \mathrm{Al}_{2} \mathrm{O}_{3}$ was produced with $\mathrm{GO}$ and $\gamma-\mathrm{Al}_{2} \mathrm{O}_{3}$ by using a hydrothermal reaction. This arrangement was accomplished by creating hydrogen bonds between hydroxyl and carboxyl functional groups on the surface of $\gamma-\mathrm{Al}_{2} \mathrm{O}_{3}$ and $\mathrm{GO}$ nanosheets [62]. The presence of GO enlarged the specific surface area of the newly created material. As a result, the fluoride adsorption rate was fast during the first $60 \mathrm{~min}$, and the adsorption equilibrium state was achieved at about $90 \mathrm{~min}$ of reaction. The findings demonstrated that the sorption capacity $\left(4.68 \mathrm{mg} \mathrm{g}^{-1}\right)$ of $\mathrm{GO} / \mathrm{Al}_{2} \mathrm{O}_{3}$ is greater than that of $\gamma-\mathrm{Al}_{2} \mathrm{O}_{3}\left(3.04 \mathrm{mg} \mathrm{g}^{-1}\right)$. Adsorption kinetics was found to follow the pseudo-second-order model, which suggests fluoride removal via chemisorption mechanism and thermodynamics showed that the fluoride adsorption behavior by $\mathrm{GO} / \mathrm{Al}_{2} \mathrm{O}_{3}$ is spontaneous with a negative $\Delta \mathrm{G}^{\circ}$ value $\left(-2.32 \mathrm{~kJ} \mathrm{~mol}^{-1}\right.$ at $\left.303 \mathrm{~K}\right)$. Additionally, the positive value of $\Delta \mathrm{H}^{\circ}\left(+24.6 \mathrm{~kJ} \mathrm{~mol}^{-1}\right)$ exhibited that fluoride adsorption by $\mathrm{GO} / \mathrm{Al}_{2} \mathrm{O}_{3}$ is endothermic in nature. Furthermore, $\mathrm{PO}_{4}{ }^{3-}$ and $\mathrm{HCO}_{3-}$ had a great influence on fluoride removal in an aqueous solution. The impact of the $\mathrm{pH}$ value on fluoride removal was relatively minor, which indicated that $\mathrm{GO} / \mathrm{Al}_{2} \mathrm{O}_{3}$ is effective within a broad range of $\mathrm{pH}$ values.

\section{Graphene Oxide-Aluminum Oxyhydroxide Interaction (GO-Al-O(OH))}

The present material refers to modification of aluminum oxyhydroxide $[\mathrm{Al}-\mathrm{O}(\mathrm{OH})]$ by graphene oxide. It was produced by a chemical precipitation wherein $\mathrm{Al}^{3+}$ ions interact with various functional groups of GO [63]. The maximum adsorption capacity of GO-Al- 
$\mathrm{O}(\mathrm{OH})$ adsorbent was $51.42 \mathrm{mg} \mathrm{g}^{-1}$ with only $2.0 \mathrm{~g}$ of the adsorbent placed in a laboratory scale column. Experiments were accomplished at $\mathrm{pH}$ 7.0, and the adsorption could be satisfactorily described by the Langmuir and Dubinin-Radushkevich isotherm models. The adsorptive rate of fluoride increased with time, providing substantial removal efficiency after $60 \mathrm{~min}$. Under these conditions, fluoride residual concentration was below the legislative limit. The negative values of $\Delta \mathrm{G}^{\circ}\left(-5.84 \mathrm{~kJ} \mathrm{~mol}^{-1}\right.$, at $\left.303 \mathrm{~K}\right)$, correspond to a spontaneous process of $\mathrm{F}$ ion adsorption onto the $\mathrm{GO}-\mathrm{Al}-\mathrm{O}(\mathrm{OH})$, while the positive value of $\Delta \mathrm{H}^{\circ}\left(+21.4 \mathrm{~kJ} \mathrm{~mol}^{-1}\right)$ indicated that the adsorption phenomenon is endothermic.

\section{Graphene Oxide/Eggshell (GO/ES) Adsorbent}

The GO/ES adsorbent has been studied for fluoride removal [64]. Eggshells are calcium-containing materials that have been used by researchers as adsorbents for $\mathrm{F}^{-}$ removal due to their solid affinity towards the pollutants of interest. GO/ES is a material that benefits from the properties of each component for better efficiency. The maximum adsorption capacity of $\mathrm{F}^{-}\left(56 \mathrm{mg} \mathrm{g}^{-1}\right)$ was obtained with $25 \mathrm{mg} \mathrm{L}^{-1}$ of $\mathrm{F}^{-}$initial concentration after $120 \mathrm{~min}$ of contact time with an adsorbent dosage of $0.05 \mathrm{~g}$ of GO/ES. Adsorption isotherms showed that the experimental data were best fitted by the Langmuir model, indicating that $\mathrm{F}^{-}$adsorption is characterized by monolayer adsorption on a homogenous surface of GO/ES. The conducted thermodynamic study showed that, as the temperature increases, an increment in $\Delta \mathrm{G}^{\circ}$ values was recorded (from $0.1865 \mathrm{~kJ} \mathrm{~mol}^{-1}$ at $298 \mathrm{~K}$ to $2.4085 \mathrm{~kJ} \mathrm{~mol}^{-1}$ at $348 \mathrm{~K}$ ), suggesting that higher temperatures render the adsorption of $\mathrm{F}^{-}$ by using GO/ES unfavorable, while the negative value of $\Delta \mathrm{H}^{\circ}\left(-12.7 \mathrm{~kJ} \mathrm{~mol}^{-1}\right)$ indicates that the adsorption process is exothermic. The disadvantage of this research is that it does not refer to the effect of $\mathrm{pH}$ and the presence of other ions that may affected the results.

\section{Graphene Oxide Anchored Sand (ZIGCS) Functionalized by Zr(IV)}

GO was manufactured from low-cost materials, sugar, and river sand, which were impregnated with zironium (Zr) (ZIGCS) and used for the de-fluoridation of water [65]. Unmodified GO cannot be considered as an efficient adsorbent due to the considerable aggregation of graphene oxide nano-sheets in water, which causes a significant loss of its high adsorption potential. This aggregation was effortlessly conquered via covering of sand particles by coating, which provided a cheap context for graphene oxide preparation. The reaction of $\mathrm{F}^{-}$on ZIGCS depended on its $\mathrm{pH}$ values, with maximum adsorption to take place at $\mathrm{pH} 4$ close to its ZPC of 4.5. However, the material was efficient enough in the whole $\mathrm{pH}$ range between 2 and 9 . The reported Langmuir maximum adsorption capacity of $175 \mathrm{mg} \mathrm{g}^{-1}$ is an above average value, compared to the other carbon-based adsorbents studied for de-fluoridation. In this study, the increase in negative $\Delta G^{\circ}$ values with a rise in temperature demonstrated that the $\mathrm{F}^{-}$adsorption by ZIGCS is thermodynamically possible and spontaneous, suggesting a favorable adsorption at high temperatures. Moreover, a positive $\Delta \mathrm{H}^{\circ}$ value indicates that the adsorption process was endothermic.

In addition, Figure 4 illustrates a schematic presentation of the presented modified graphene oxide-based materials, their optimum $\mathrm{pH}$ values, their relative adsorption capacities, and the contact time for optimized adsorption. 


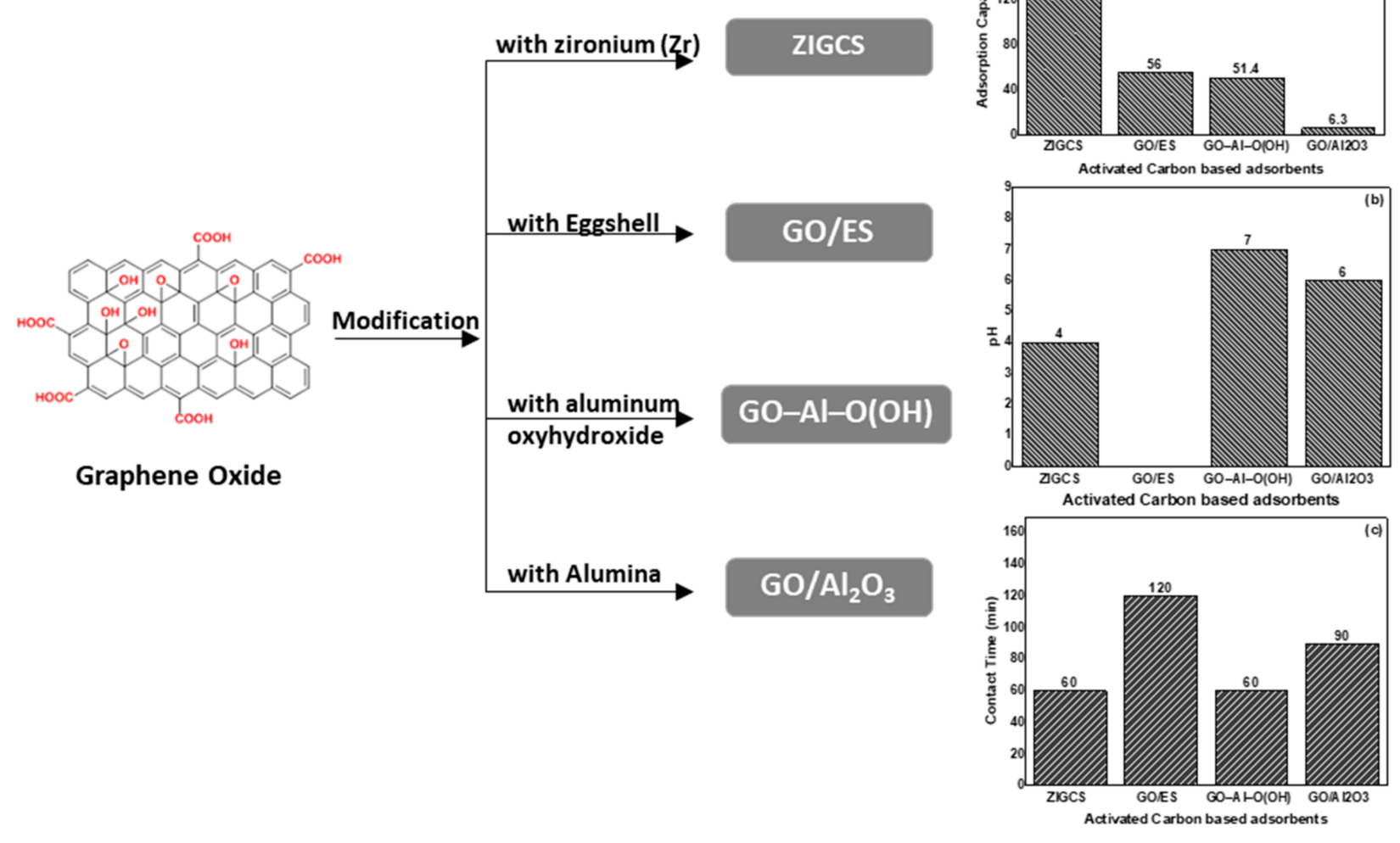

Figure 4. Schematic presentation of modified graphene oxide-based materials used for fluoride removal showing (a) the optimu $\mathrm{pH}$ optimum, (b) the maximum adsorption capacities, and (c) the contact time of adsorption.

In more detail, Figure 5 presents the maximum adsorption capacities $\left(\mathrm{mg} \mathrm{g}^{-1}\right)$ of modified graphene oxide materials. As shown, ZIGCS is the graphene-based material that presents a maximum adsorption capacity of $175 \mathrm{mg} \mathrm{g}^{-1}$, among the other materials reviewed in this study.

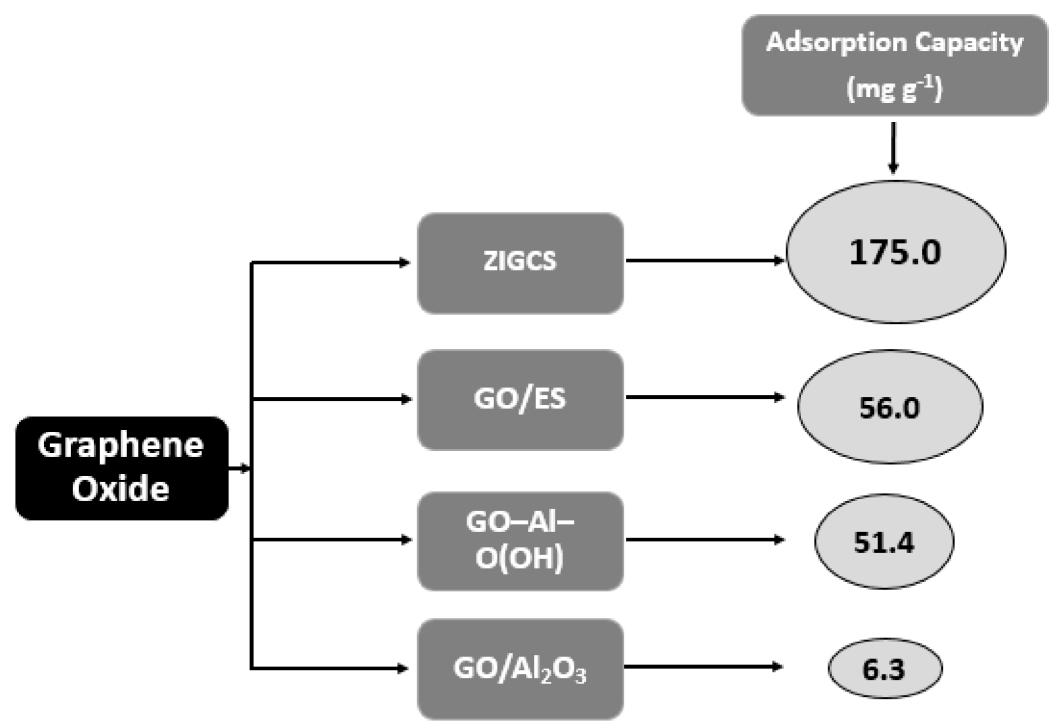

Figure 5. Schematic graph of depicting maximum adsorption capacities $\left(\mathrm{mg} \mathrm{g}^{-1}\right)$ of presented graphene oxide-based materials. 


\subsubsection{Carbon Nanotubes (CNTs)}

Carbon nanotubes, an allotrope of carbon, have uncommon features which are important in nano-technology. Furthermore, due to their potential for being functionalized by appropriate reactive groups and their one dimensional structure, the characteristics of CNTs can easily be controlled and improved [66]. In the last three years, however, there has been no extensive research into their use to remove fluoride.

\section{Hydroxyapatite/Multi-Walled Carbon Nanotubes (HA-MWCNTs)}

The production of MWCNTs was made using a simple in situ sol-gel method, and was used for the removal of fluoride from water [67]. Based on the results achieved in the study of Ruan et al. [67], HA-MWCNTs exhibited a high fluoride adsorption capacity of $39.22 \mathrm{mg} \mathrm{g}^{-1}$ at $323 \mathrm{~K}$ and an adsorbent dose of $2.0 \mathrm{~g} \mathrm{~L}^{-1}$ at $\mathrm{pH}$ 7.0. The adsorption reaction was spontaneous $\left(\Delta \mathrm{G}^{\circ}=-1.964 \mathrm{~kJ} \mathrm{~mol}^{-1}\right.$ at $\left.303 \mathrm{~K}\right)$ and endothermic $\left(\Delta \mathrm{H}^{\circ}=+6.4 \mathrm{~kJ} \mathrm{~mol}^{-1}\right)$ and appeared to occur as a result of both anion exchange and electrostatic interactions. The removal of fluoride by the composite was observed to be firmly reliant on the experimental conditions, which included temperature, contact time, solution $\mathrm{pH}$, and interfering of other co-occurring anions such as $\mathrm{HCO}_{3}{ }^{-}, \mathrm{CO}_{3}{ }^{2-}$, and $\mathrm{C}_{2} \mathrm{O}_{4}{ }^{2-}$. These anions exhibited the following order: $\mathrm{K}_{\mathrm{h}}\left(\mathrm{CO}_{3}{ }^{2-}\right)>\mathrm{K}_{\mathrm{h}}\left(\mathrm{HCO}_{3}{ }^{-}\right)>\mathrm{K}_{\mathrm{h}}\left(\mathrm{C}_{2} \mathrm{O}_{4}{ }^{2-}\right)$. Figure 6 presents the major characteristics of carbon nanotube-based material applied for fluoride removal and reviewed in the present study.

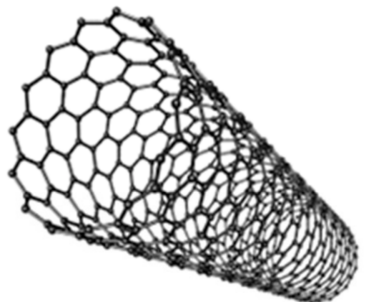

Carbon Nanotubes

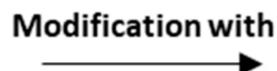

Hydroxyapatite/ multi-walled

\section{HA-MWCNTs}

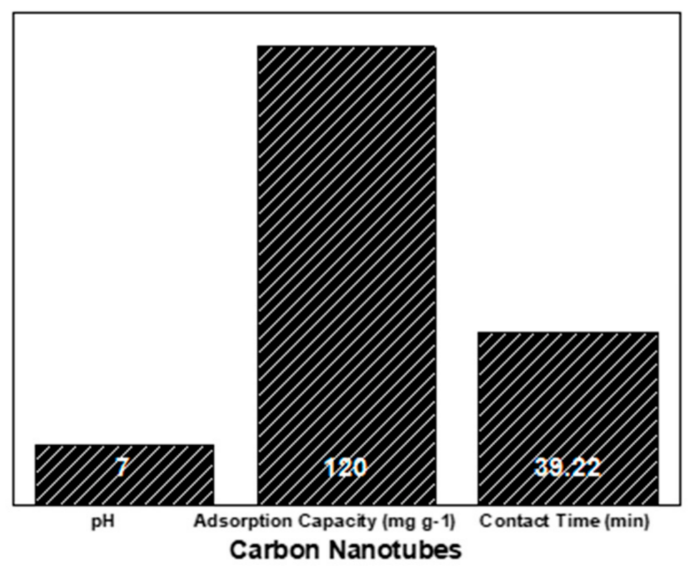

Figure 6. Schematic presentation of modified carbon nanotube-based material used for fluoride removal showing the optimum $\mathrm{pH}$ optimum, the maximum adsorption capacity, and the required contact time.

\subsection{Other Adsorbents}

Beside the use of adsorbents based on carbon, there is a broad range of new materials (mainly nanostructured) that are well applied to remove fluoride, combining metals and their oxides or hydroxides as well as natural materials.

\subsubsection{SRH Adsorbent}

Recently, Pillai et al. [68] synthesized a silica nano adsorbent altered by rice husk for fluoride removal, which is economic and gives a decent result with respect to fluoride removal. Various parameters affect its de-fluoridation efficiency. The results revealed a superb efficiency for fluoride removal with a reported adsorption capacity of $12 \mathrm{mg} \mathrm{g}^{-1}$, obtained with a dose of $4 \mathrm{~g} \mathrm{~L}^{-1}$ corresponding to $72 \%$ fluoride removal efficiency. The result of the equilibrium data follows the Langmuir isotherm.

\subsubsection{Fe@BDC and Fe@ABDC Fe-Based MOF Composites}

Synthesis of $\mathrm{Fe}^{3+}$ fabricated BDC and ABDC provides Fe@BDC and Fe@ABDC MOF composites, which can be applied for effective de-fluoridation from aqueous solutions [69]. 
The improved DC of Fe@BDC and Fe@ABDC MOF composites offered an adsorption capacity of 4.90 and $4.92 \mathrm{mg} \mathrm{g}^{-1}$, which were fitted to Langmuir isotherm model. Thermodynamic parameters exhibited that the de-fluoridation process onto Fe@BDC and Fe@ABDC MOF composites was spontaneous and feasible in nature because of negative values of $\Delta \mathrm{G}^{\circ}\left(-7.31\right.$ and $-8.15 \mathrm{~kJ} \mathrm{~mol}^{-1}$ at $303 \mathrm{~K}$, respectively). Additionally, the positive $\Delta \mathrm{H}^{\circ}$ values (+0.6 and $+1.2 \mathrm{~kJ} \mathrm{~mol}^{-1}$ for Fe@BDC and Fe@ABDC MOF composites) exhibited the nature of fluoride adsorption process, which was considered to be an endothermic chemical adsorption. The recycle of the Fe@BDC and Fe@ABDC MOF composites were executed for six cycles.

\subsubsection{Modified Kaolin-Bentonite Composites (KBNPs)}

The incorporation of nanoparticles of iron oxides in kaolin-bentonite composite adsorbents for fluoride adsorption from drinking water was studied by Annan et al. [70]. The adsorption of $\mathrm{F}^{-}$was noticed to be better described by the Freundlich isotherm model, and a pseudo-second-order kinetic model was fitted well to describe the kinetics of adsorption. The results evidently show that the saturation of clays with magnetite nanoparticles has a considerable effect on $\mathrm{F}^{-}$removal. The newly synthesized material showed a maximum percentage removal of $91 \%$ after a 120 min contact time. This study undoubtedly demonstrated that a sustainable approach for the design of filtration systems for the removal of fluoride from groundwater can be applied by using cheap components which are also locally accessible.

\subsubsection{Ce $\backslash$ Zn Ceramic Oxides}

Corresponding published results show that [71] the metal oxides of cerium (Ce) and manganese $(\mathrm{Mn})$ produced by a precipitation method have exceptionally high fluoride sorption abilities. The synthesis of bimetallic oxides such as $\mathrm{Al} \backslash \mathrm{Ce}$ or $\mathrm{Ce} \backslash \mathrm{Zn}$ has exhibited an even higher effectiveness, mainly attributed to the elevated density of hydroxyl groups. Particularly, Ce $\backslash \mathrm{Mn}$ ceramic oxide manufactured for $4 \mathrm{~h}$ showed a fluoride adsorption capacity of up to $257.8 \mathrm{mg} \mathrm{g}^{-1}$. In comparison, this value is 1.6 times superior to the adsorption capacity of Ce $\backslash \mathrm{Mn}$ synthesized for $1 \mathrm{~h}$. Likewise, this material presented rapid kinetics with $68 \%$ of fluoride initial concentration to be retained by the adsorbent in the first $5 \mathrm{~min}$, reaching equilibrium after $15 \mathrm{~min}$.

\subsubsection{Porous $\mathrm{MgO}$ Nanostructures}

According to Borgohain et al. [72], the $\mathrm{MgO}$ nanostructures of diverse morphologies have been formulated by the sol-gel and hydrothermal method in an aqueous medium in the absence of additional templates. The $\mathrm{MgO}$ nanostructures are exceedingly crystalline and porous, having an elevated surface area within the range from 10.5 to $171.2 \mathrm{~m}^{2} \mathrm{~g}^{-1}$. Their morphology depends on the synthesis approach as well as the metal ion precursor. The kinetic studies indicated that adsorption is very fast and that the $\mathrm{MgO}$ nanostructures present high retention capability (varied from 5716 to $15,691 \mathrm{mg} \mathrm{g}^{-1}$ at $303 \mathrm{~K}$ ) and follow the Langmuir model. The utmost Langmuir adsorption capacity of $29,131 \mathrm{mg} \mathrm{g}^{-1}$ has been achieved at $313 \mathrm{~K}$, which is the best result between all adsorbents described until in this review. Negative value of Gibbs free energy $\left(\Delta \mathrm{G}^{\circ}=-21.1 \mathrm{~kJ} \mathrm{~mol}^{-1}\right.$ at $\left.303 \mathrm{~K}\right)$ for this adsorbent, suggests a thermodynamically favorable interaction between fluoride and the adsorbent, while the negative value of $\Delta \mathrm{H}^{\circ}\left(-47.6 \mathrm{~kJ} \mathrm{~mol}^{-1}\right)$ indicates that the adsorption is an exothermic process.

\subsubsection{Lanthanum Modified Mesoporous Alumina (La/MA)}

The elimination of $\mathrm{F}^{-}$from aqueous solutions utilizing $\mathrm{La} / \mathrm{M}$ was examined by $\mathrm{He}$ et al. [73]. The Elovich kinetic model was proven to offer the best correlation for the adsorption. The highest monolayer adsorption capacity of $\mathrm{F}^{-}$was about $26.45 \mathrm{mg} \mathrm{g}^{-1}$ in the Sips model (at a dosage of $2.0 \mathrm{~g} \mathrm{~L}^{-1}$ ) and had slightly acidic conditions ( $\mathrm{pH}=6.0 \pm 0.1$ ). Negative values of $\Delta \mathrm{G}^{\circ}$ (i.e., $-3.761 \mathrm{~kJ} \mathrm{~mol}^{-1}$ at $298 \mathrm{~K}$ ) indicated that the adsorption 
process was feasible and spontaneous. The positive value of enthalpy $\left(+3.9 \mathrm{~kJ} \mathrm{~mol}^{-1}\right)$ showed that the adsorption was endothermic. Still, the influence of co-existed anions on $\mathrm{F}^{-}$removal was investigated, and it was indicated that the removal efficiency was vaguely affected by the presence of $\mathrm{Cl}^{-}$and $\mathrm{NO}^{3-}$, whereas $\mathrm{SO}_{4}{ }^{2-}$ and $\mathrm{CO}_{3}{ }^{2-}$ caused a sharp decrease in the removal efficiency. In the same study, while cerium modified mesoporous alumina (Ce/MA) was also analyzed for its efficiency, the La/MA was a better adsorbent than the employed Ce/MA.

\subsubsection{Iron Oxide Nanoparticles Modified with Ionic Liquid (IL-Iron Oxide)}

A new material, IL-iron oxide NPs was manufactured by the co-precipitation method using ionic liquids (IL) as a solvent and trihexyl(tetradecyl)phosphonium chloride [THTDP]Cl as a coating material [74]. The main part between IL-iron oxide and fluoride ion was an electrostatic attraction which concurrently enhanced the elimination of fluoride. An investigation of kinetics confirmed that fluoride elimination was enhanced rapidly during the starting period, and the highest fluoride retention efficiency was achieved in $30 \mathrm{~min}$. The best isotherm model was the Langmuir model which revealed a sorption capability of $67.9 \mathrm{mg} \mathrm{g}^{-1}$ with ceiling fluoride removal of $96 \%$. Thermodynamic results showed that $\Delta \mathrm{G}^{\circ}$ decreased with a rise in temperature (from $-15.6 \mathrm{~kJ} \mathrm{~mol}^{-1}$ at $283 \mathrm{~K}$ to $-60 \mathrm{~kJ} \mathrm{~mol}^{-1}$ at $303 \mathrm{~K})$ with positive $\Delta \mathrm{H}$ values $\left(\Delta \mathrm{H}^{\circ}=+6.6 \mathrm{~kJ} \mathrm{~mol}^{-1}\right)$ indicating the spontaneous and endothermic nature of the fluoride adsorption.

\subsection{8. $\gamma-\mathrm{Al}_{2} \mathrm{O}_{3} / \gamma-\mathrm{Fe}_{2} \mathrm{O}_{3}$ Composite}

A recyclable mesoporous magnetic adsorbent of $\gamma-\mathrm{Al}_{2} \mathrm{O}_{3} / \gamma-\mathrm{Fe}_{2} \mathrm{O}_{3}$ nanocomposite was produced by Roy [75] by a microwave irradiation method. Fluoride adsorption equilibrium was accomplished within $15 \mathrm{~min}$ and the maximum adsorption capacity of $\gamma-\mathrm{Al}_{2} \mathrm{O}_{3} / \gamma-\mathrm{Fe}_{2} \mathrm{O}_{3}$ nanocomposite was $105.04 \mathrm{mg} \mathrm{g}^{-1}$ at $\mathrm{pH}$ 7.0, which is better than several other reported adsorbents, by using $1.0 \mathrm{~g} \mathrm{~L}^{-1}$ of adsorbent dosage. Thermodynamics showed that the negative value of $\Delta \mathrm{G}^{\circ}\left(-27.326 \mathrm{~kJ} \mathrm{~mol}^{-1}\right.$ at $\left.303 \mathrm{~K}\right)$ and the positive value of $\Delta \mathrm{H}^{\circ}\left(+14.4 \mathrm{~kJ} \mathrm{~mol}^{-1}\right)$ suggest the adsorption process is favorable, spontaneous, and endothermic, accordingly. The adsorption process followed the Langmuir model. The nanocomposite has a superior affinity for fluoride ions in the presence of other interfering co-existing anions. Therefore, the conclusion of this study demonstrated the prospective ability of $\gamma-\mathrm{Al}_{2} \mathrm{O}_{3} / \gamma-\mathrm{Fe}_{2} \mathrm{O}_{3}$ nanocomposite to develop an efficient adsorbent for fluoride

\subsubsection{Zirconium-Based Metal Organic Framework (MOF-801) Adsorbent}

A MOF-801 adsorbent, applying a solvothermal method and investigating its adsorption effectiveness for removal of F- from water, was studied by Tan et al. [76]. The produced MOF-801 had a surface area of $522 \mathrm{~m}^{2} \mathrm{~g}^{-1}$ and exhibited superb performance in the adsorption of fluoride from water, with an optimum adsorption amount for fluoride of up to $17.33 \mathrm{mg} \mathrm{g}^{-1}$ at a dosage of $1 \mathrm{~g} \mathrm{~L}^{-1}$. The kinetic studies showed that the adsorption of fluoride is described by the Langmuir isotherm model and could be well fitted with pseudo-second-order model, hence presuming that fluoride adsorption on MOF-801 relies on chemisorption. The summarized findings implied that the synthesized MOF-801 has the ability to be an outstanding technology.

\subsubsection{Biosynthetic Crystals by Microbially Induced Calcium Carbonate Precipitation (BC-ICP)}

$\mathrm{BC}$ were made according to the process of Wang et al. [77] through microbially induced calcium carbonate precipitation (MICP) for fluoride removal from groundwaters. The findings revealed that the maximum fluoride adsorption capability and defluorination efficiency reached $5.10 \mathrm{mg} \mathrm{g}^{-1}$ and $98.24 \%$, at $\mathrm{pH} 7.0$ and a $\mathrm{BC}$ dose of $1.0 \mathrm{~g} \mathrm{~L}^{-1}$, respectively. The fluoride adsorption on $\mathrm{BC}$ was observed to be a heterogeneous and multilayered adsorption process, principally dominated by chemisorption, and the Freundlich isotherm model better described the reaction. The mechanism that occurs in the adsorption and precipitation of fluoride by $\mathrm{BC}$ takes place simultaneously with the co-precipitation 
of $\mathrm{Ca}^{2+}, \mathrm{PO}_{4}{ }^{3-}$ and $\mathrm{F}^{-}$. As the fluoride adsorbs onto the surface of $\mathrm{BC}$, induced calcium ions (from calcium carbonate) precipitate into the $\mathrm{CaF}_{2}$. As exhibited from the thermodynamics study, $\Delta G^{\circ}$ decreased with the rise in temperature and the negative value of $\Delta \mathrm{G}^{\circ}\left(-4.60 \mathrm{~kJ} \mathrm{~mol}^{-1}\right.$ at $\left.303 \mathrm{~K}\right)$ indicate that the adsorption process was spontaneous and thermodynamically favorable in nature. $\Delta \mathrm{H}^{\circ}\left(+2.3 \mathrm{~kJ} \mathrm{~mol}^{-1}\right)$ had positive values, which suggested an endothermic adsorption process. The method is efficient for longer periods of operation and can be applied in full scale fluidized bed reactors.

\subsubsection{Lanthanum Ferrite Nanoparticles $\left(\mathrm{LaFeO}_{3} \mathrm{NPs}\right)$}

Mesbah et al. [78] aimed to produce $\mathrm{LaFeO}_{3} \mathrm{NPs}$ and examine its efficiency on the elimination of fluoride from waters. The largest percentage removal of $94.75 \%$ fluoride on $\mathrm{LaFeO}_{3} \mathrm{NPs}$ was achieved under optimum conditions of $\mathrm{pH}$ of $5, \mathrm{LaFeO}_{3} \mathrm{NPs}$ dosage of $0.9 \mathrm{~g} \mathrm{~L}$, a temperature of $308 \mathrm{~K}$, and a contact time of $60 \mathrm{~min}$. The process of fluoride adsorption on $\mathrm{LaFeO}_{3} \mathrm{NPs}$ followed the Freundlich adsorption and Koble-Corrigan isotherm models. The negative $\Delta \mathrm{H}^{\circ}$ value of the sorption suggests that the process was exothermic. The increase in temperature resulted in an increase in spontaneity and feasibility, while the values of $\Delta \mathrm{G}^{\circ}$ were negative (i.e., $-4.06 \mathrm{~kJ} \mathrm{~mol}^{-1}$ at $308 \mathrm{~K}$ ).

A schematic presentation of the four most efficient presented materials is showed in Figure 7.
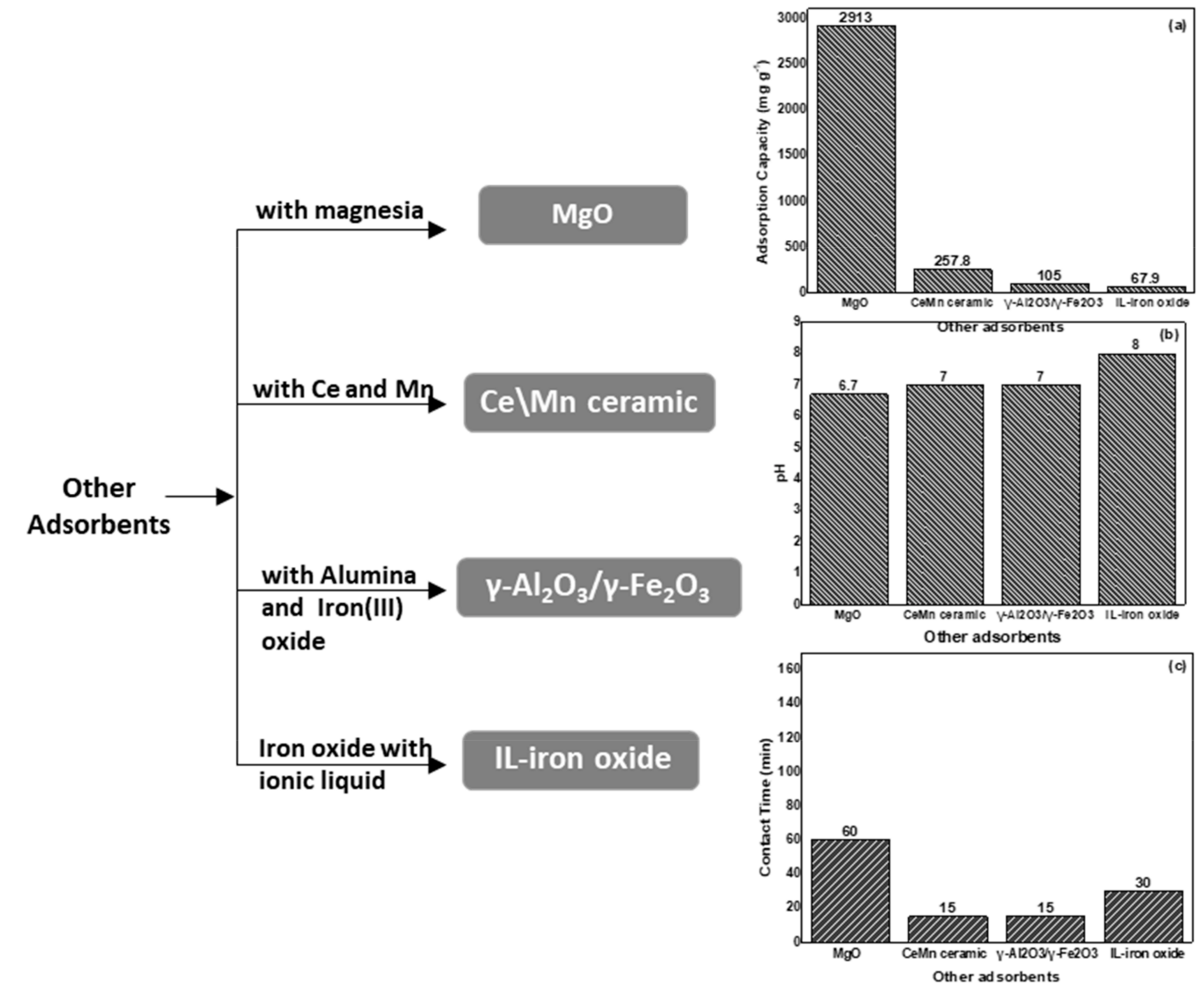

Figure 7. Schematic presentation of the four most efficient presented materials used for fluoride removal, showing the modification type, (a) the $\mathrm{pH}$ optimum activity, (b) the maximum adsorption capacities and the contact time (c) of adsorption. 
In more detail, Figure 8 shows in descending order the maximum adsorption capacities $\left(\mathrm{mg} \mathrm{g}^{-1}\right)$ of the four most efficient materials. Among them, the $\mathrm{MgO}$ nanostructures exhibited the highest adsorption capacity $\left(29,131 \mathrm{mg} \mathrm{g}^{-1}\right)$ of all of the presented materials.

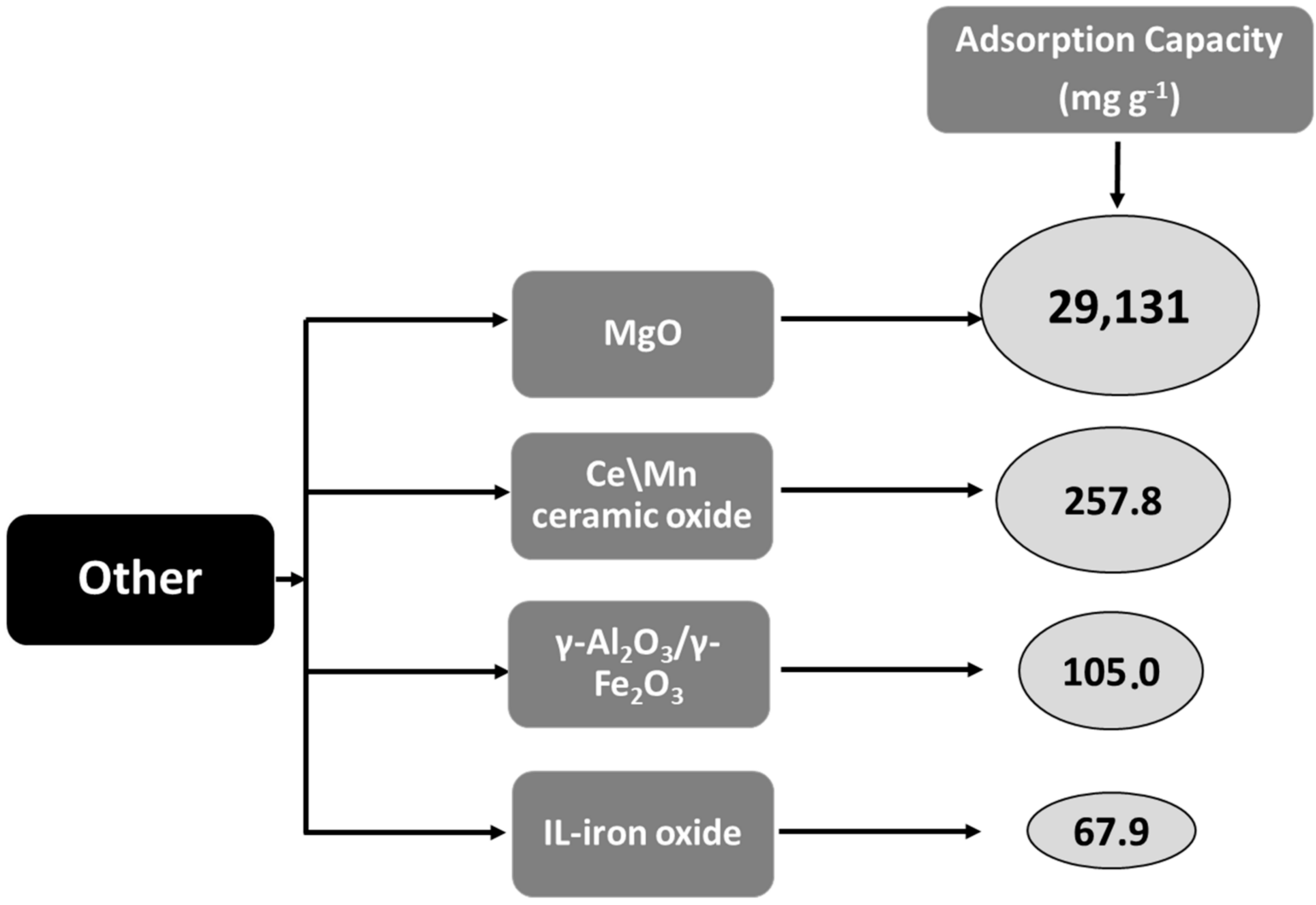

Figure 8. Schematic graph depicting maximum adsorption capacities $\left(\mathrm{mg} \mathrm{g}^{-1}\right)$ of the four most efficient presented materials.

Table 2 shows the reviewed materials when employed for removal of fluoride from waters and offers evidences about their applications in water treatment. As shown in this Table, most of the recommended materials are efficient at $\mathrm{pH}$ values around 7 . Interest was given to the application of novel materials based on GO, providing high adsorption capacity. Observing the recent literature, in the last two to three years, it is worth noting that the use of La in the modification of materials, both activated carbon as well as hybrid materials (i.e., $\mathrm{La} / \mathrm{Mg} / \mathrm{Si}-\mathrm{AC}$, La/MA, $\mathrm{LaFeO}_{3} \mathrm{NPs}$ ) $[58,75]$, has been successfully increased. However, by using $\mathrm{MgO}$ nanostructures [72], a maximum Langmuir adsorption capacity of $29,131 \mathrm{mg} \mathrm{g}^{-1}$ has been achieved, which is the greatest for any adsorbing material described until to date.

Results from the regeneration experiments performed on most of the materials reviewed, in order to test the usability of the adsorbents, showed that all of the materials can be recycled from three to six cycles. This is considered as not very efficient, since nowadays in the production of materials almost 20 cycles of regeneration are feasible. Therefore, in this area there is more work to be done.

Many of the reviewed articles presented results on the adsorption thermodynamic behavior of the materials studied in order to indicate the feasibility of the adsorption processes. The thermodynamic parameter which reflects whether the process is spontaneous is the $\Delta \mathrm{G}^{\circ}$, which is related to the equilibrium constant of the reaction. A spontaneous reaction releases free energy, and so the sign of $\Delta \mathrm{G}^{\circ}$ is negative. If the Gibbs energy of the process is favourable (negative), the process is enhanced at higher temperatures [51,52]. $\Delta \mathrm{H}^{\circ}$ contributes to the Gibbs energy. Exothermic adsorption processes have $\Delta \mathrm{H}^{\circ}<0$, and are considered endothermic when $\Delta \mathrm{H}^{\circ}>0$ [79]. Therefore, a rise in the adsorption 
capability with a temperature increase implies an endothermic adsorption procedure, while a decrease in the adsorption capacity with a temperature increase suggests an exothermic process $[79,80]$. Comparing the studies referred in this review article (Table 2) reveals that the only absorbents that provided negative $\Delta \mathrm{G}^{\circ}$ and $\Delta \mathrm{H}^{\circ}$ values were the $\mathrm{MgO}$ [72] and $\mathrm{LaFeO}_{3} \mathrm{NPs}$ [78]. The majority of the compared adsorbents indicate that the adsorption process was spontaneous (based on the negative values of Gibbs free energy, and the 75\% provided adsorption of an endothermic nature). There is only one study in this review that presented a positive value of $\Delta \mathrm{G}^{\circ}$, namely the GO/ES adsorbent [64], indicating that it undergoes a physio-sorption process.

Table 2. Novel carbon-based and nanostructured materials utilized for the removal of fluoride from waters. Comparison of their basic characteristics.

\begin{tabular}{|c|c|c|c|c|c|c|c|c|}
\hline Adsorbent & $\mathrm{pH}$ & $\begin{array}{c}\text { Adsorbent } \\
\text { Dosage } \\
\left(\mathrm{g} \mathrm{L}^{-1}\right)\end{array}$ & $\begin{array}{l}\text { Time } \\
\text { (min) }\end{array}$ & $\begin{array}{c}\text { Adsorption } \\
\text { Capacity } \\
\left(\mathrm{mg} \mathrm{g}^{-1}\right)\end{array}$ & $\begin{array}{l}\text { Regeneration } \\
\text { (Cycles) }\end{array}$ & $\begin{array}{c}\Delta \mathrm{G}^{\circ} \\
\left(\mathrm{kJ} \mathrm{mol}^{-1}\right)(\text { at } 303 \mathrm{~K})\end{array}$ & $\begin{array}{c}\Delta \mathrm{H}^{\circ} \\
\left(\mathrm{kJ} \mathrm{mol}^{-1}\right)\end{array}$ & Ref. \\
\hline \multicolumn{9}{|c|}{ Activated Carbon Based Adsorbents } \\
\hline $\mathrm{Zr}-\mathrm{ACF}$ & 7.0 & 2.0 & 30 & 28.50 & - & $<0$ & $>0$ & [50] \\
\hline ACAS & 6.0 & 19.0 & 60 & 1.20 & - & - & - & [54] \\
\hline AC-CMCSL & 4.5 & 15.0 & 70 & 2.01 & - & -0.20576 & +22.6 & [55] \\
\hline $\mathrm{La} / \mathrm{Mg} / \mathrm{Si}-\mathrm{AC}$ & 8.0 & 0.2 & 150 & 220.5 & 5 & $-1.41 \times 10^{4}($ at $308 \mathrm{~K})$ & $+7.5 \times 10^{3}$ & [56] \\
\hline \multicolumn{9}{|c|}{ Graphene Oxide Based Adsorbents } \\
\hline $\mathrm{GO} / \mathrm{Al}_{2} \mathrm{O}_{3}$ & 6.0 & 8.0 & 90 & 6.30 & 4 & -2.32 & +24.6 & [62] \\
\hline $\mathrm{GO}-\mathrm{Al}-\mathrm{O}(\mathrm{OH})$ & 7.0 & 2.0 & 60 & 51.42 & - & -5.84 & +21.4 & [63] \\
\hline GO/ES & - & 0.05 & 120 & 56.0 & - & 0.1865 (at $298 \mathrm{~K}$ ) & -12.7 & [64] \\
\hline ZIGCS & 4.0 & 2.0 & 60 & 175.0 & 5 & -0.045 (at $308 \mathrm{~K})$ & +30.6 & [65] \\
\hline \multicolumn{9}{|c|}{ Carbon Nanotubes Based Adsorbents } \\
\hline HA-MWCNTs & 7.0 & 2.0 & 120 & 39.22 & - & -1.964 & +6.4 & [67] \\
\hline \multicolumn{9}{|c|}{ Other Adsorbents } \\
\hline SRH & 8.0 & 4.0 & 60 & 6.0 & 4 & +2.6 & +2.6 & [68] \\
\hline $\begin{array}{c}\text { Fe@BDC \& } \\
\text { Fe@ABDC MOF }\end{array}$ & 6.6 & 0.1 & 60 & $4.90 \& 4.92$ & 6 & $+0.6 \&+1.2$ & $+0.6 \&+1.2$ & [69] \\
\hline KBNPs & 6.5 & 6.0 & 120 & 1.72 & - & - & - & [70] \\
\hline $\begin{array}{l}\mathrm{Ce} \backslash \text { Mn ceramic } \\
\text { oxide }\end{array}$ & 7.0 & - & 15 & 257.8 & - & - & - & [71] \\
\hline $\mathrm{MgO}$ & 6.7 & 0.2 & 60 & 29,131 & 5 & -47.6 & -47.6 & [72] \\
\hline $\mathrm{La} / \mathrm{MA}$ & 6.0 & 2.0 & 60 & 26.45 & 5 & +3.9 & +3.9 & [73] \\
\hline IL-iron oxide & 8.0 & 0.06 & 30 & 67.9 & 3 & +6.6 & +6.6 & [74] \\
\hline $\begin{array}{c}\gamma-\mathrm{Al}_{2} \mathrm{O}_{3} / \gamma- \\
\mathrm{Fe}_{2} \mathrm{O}_{3}\end{array}$ & 7.0 & 1.0 & 15 & 105.04 & 5 & +14.4 & +14.4 & [75] \\
\hline MOF-801 & - & 1.0 & 120 & 17.33 & 4 & - & - & [76] \\
\hline BC-ICP & 7.0 & 1.0 & - & 5.10 & - & +2.3 & +2.3 & [77] \\
\hline $\mathrm{LaFeO}_{3} \mathrm{NPs}$ & 5.0 & 0.9 & 60 & 2.58 & - & -0.51 & -0.51 & [78] \\
\hline
\end{tabular}

\section{Analytical Methods for Fluoride Determination in Drinking Water}

In this section the typical analytical techniques that are employed for the determination of fluoride in drinking water are discussed. Figure 9 presents the percentage distribution of the different methods for the determination of fluoride in drinking water. 


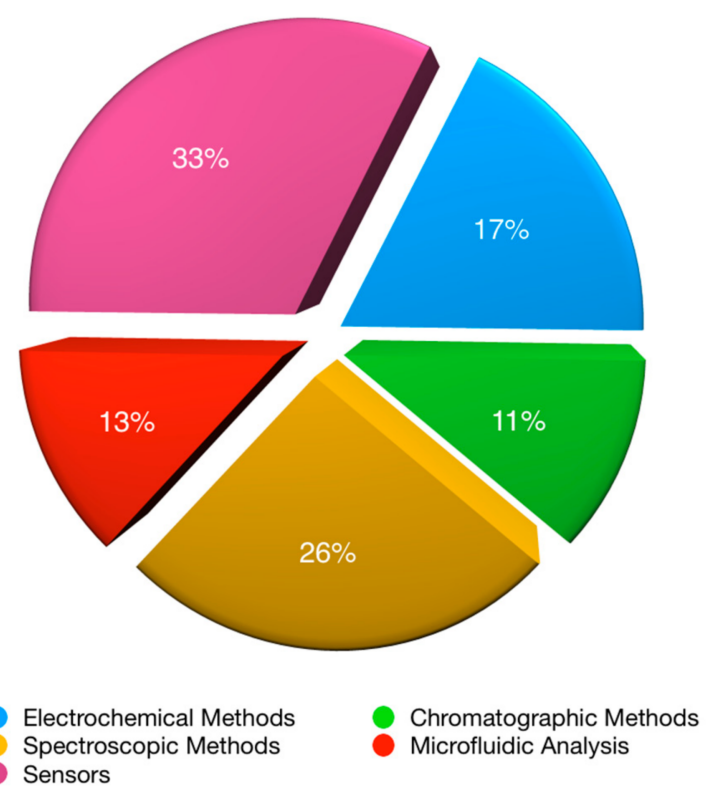

Figure 9. Analytical techniques for the determination of fluoride in drinking water.

\subsection{Electrochemical Methods}

There is a great variety of different analytical techniques regarding the determination of fluoride in water samples. Electroanalytical methods (i.e., potentiometry [81-86], voltammetry [87], and polarography [88]) are the oldest analytical techniques that have been employed to assess the concentration of fluoride in drinking water since the introduction of the first fluoride ion-selective electrode in 1966 by Frant and Ross [89]. At the same time, and in order to provide preconcentration of the fluoride, various materials have been proposed including zirconia (which is an inorganic ion exchanger that can rapidly and selective adsorb fluoride ions from acidic solutions [84]) and a complex of $\mathrm{Zr}$ (IV) with a hydrophilic resin having an iminodiacetic acid [83]. Mao et al. [87] prepared two-different apatite solid-phase microextraction (SPME) coatings (i.e., dicalcium phosphate dihydrate and hydroxyapatite by one-step electrodepositition on glassy carbon electrodes). Both coatings showed good adsorbability towards fluoride ions. Typically, the utilization of electrochemical methods and ion-selective electrodes has many benefits including handling simplicity and reduced cost (compared to chromatographic methods and spectroscopic methods). Moreover, they are rapid and non-destructive. On the other hand, ion-selective electrodes are affected by various changes (e.g., in temperature and in shift potential), as well as by the presence of interfering ions [36].

\subsection{Chromatographic Methods}

A plethora of chromatographic methods, utilizing IC, HPLC and GC regarding fluoride determination have been published. IC is a powerful technique for the determination of fluorides in water samples at trace levels [90]. IC is normally employed for the separation and the quantitative determination of ionic species. The separation of the target analyte is typically performed based on ionic interactions among the compounds of interest, as well as the ions and the ionic groups of the mobile and the stationary phase, respectively [33,91]. IC has been successfully employed for the determination of fluoride in drinking waters [92,93]. Stability, reproducibility, and simplicity are among the advantages of IC. However, since the fluoride ions are weakly retained by anion-exchange resins, its ion peak is too close to its injection peak. Moreover, there is a significant interference from mono carboxylic acids that co-elute with fluorides $[33,94]$. Finally, the cost of chromatographic systems, such as IC, is higher than the cost of other techniques (e.g., ion-selective electrodes). Therefore, there are limitations on the use of IC in developing countries [36]. 
Jones et al. [92] developed an IC method for the determination of fluoride in water samples based on the formation of chromatographically stable $\mathrm{AlF}^{2+}$ species III in the presence of excess aluminum. The authors mentioned that while the magnesium in relatively large amounts interferes with fluoride ions, a modification of the eluent and/or post-column reaction $\mathrm{pH}$ can reduce this unwanted phenomenon. Bayón et al. [93] developed an IC method for the indirect determination of trace amounts of fluoride in natural waters that was also based on the formation of the aluminum monofluoride complex. In this approach, two detection techniques were employed (i.e., on-line post-column fluorimetry and ICPMS). For the former approach, the detection was achieved by a post-column reaction of the species with 8-hydroxyquinoline-5-sulfonic acid in a micellar medium of cetyltrimethylammonium bromide, while EDTA was added to the sample solution to overcome interferences from iron. For the latter approach, the indirect determination of fluoride was achieved by monitoring aluminum at mass 27 . However, regarding the ICP-MS instruments it must be stated that its operation cost, time, and complexity limits its applications for fluoride detection in developing countries [36].

HPLC has also been employed for the determination of fluoride in water samples. HPLC is a standard piece of equipment that can be found in many laboratories and, thus, it is a convenient tool for fluoride's determination. The utilization of HPLC can help overcome the limitations of IC (e.g., the frequently overlapping peak of fluoride and void volume peaks) [95]. Musijowksi et al. [95] proposed the determination of fluoride as a fluorosilane derivative using reversed-phase HPLC with ultraviolet (UV) detection for the determination of total organic fluorine. For this purpose, triphenylhydroxysilane was employed as derivatizing agent, while the derivatization reaction took place in highly acidic conditions, followed by extraction of the obtained product by $n$-heptane. Xu et al. [96] proposed the determination of fluoride in water samples by reversed-phase HPLC coupled with a photodiode array detector (PDA) using $\mathrm{F}^{-}-\mathrm{La}^{3+}$-alizarin complexone ternary complexes. The developed method exhibited good sensitivity and was successfully employed for the analysis of river and tap water samples.

Gas chromatography-mass spectrometry (GC-MS) has been also proposed for the determination of fluoride in drinking water samples. For this purpose, Pagliano et al. [97] developed a one-step ethyl-derivatization approach to generate volatile fluorethane derivatives using triethyloxonium tetrachloroferrate(III) as a derivatizing agent. After its formation, gaseous fluoroethane was separated from the matrix, sampled from the headspace, and determined by GC-MS. In this approach, no organic solvents were required, and the derivatizing agent was nonvolatile and, thus, safe to use.

\subsection{Spectroscopic Methods}

While fluorine is the most electronegative element which exhibits a very high ionization potential, its resonance lines are located in the vacuum-UV range below $100 \mathrm{~nm}$. As a result, the determination of fluorine by atomic spectroscopic techniques such as atomic absorption spectrometry (AAS) and inductively coupled plasma optical emission spectrometry (ICP-OES) is not feasible. Moreover, since the ionization potential of argon, which is typically used in ICP systems, is not enough to cause fluorine ionization when it is introduced in aqueous solution, inductively coupled plasma mass spectrometry (ICP-MS) cannot be used either for fluorine determination [98]. An alternative technique for fluorine determination is molecular absorption spectrometry (MAS) in flames and furnaces that was proposed in the 1970s. The spectrometers that are typically used in conventional AAS are not applied for MAS due to background correction errors and spectral interferences [98]. In order to overcome this limitation, high-resolution continuum source AAS (HR-CS AAS), which offers high resolution by the utilization of a double monochromator and an echelle grating, can be employed. The determination of fluoride by high-resolution continuum molecular absorption spectrometry (HR-CS MAS) [99], and high-resolution continuum atomic absorption spectrometry graphite furnace atomic absorption spectrometry (HR-CS GFAAS) [100] have been proposed. Gleisner et al. [98] optimized a procedure for the 
determination of fluorine in drinking water samples via the MAS of gallium mono-fluoride, previously proposed by Heitmann et al. [100], utilizing a commercially available HR-CS AAS with a transversely heated graphite tube furnace. Kovacs et al. [101] proposed the indirect determination of fluoride in aqueous samples by ICP-OES following precipitation of $\mathrm{CeF}_{3}$. Four cations (i.e., yttrium(III), strontium(II), cerium(III) and lanthanum(III)) were evaluated, and cerium(III) was found to be the optimum precipitate. Moreover, the authors reported that the presence of sulphate ions is crucial for the enhancement of precipitation.

Apart from the atomic spectroscopic techniques that are available for fluorine determination, a wide variety of molecular spectrometric techniques have been also proposed. The benefits of those methods include their simplicity, their low cost, and their reliability [102]. In 1998, Khalifa and Hafez [103] proposed a spectrophotometric method for the determination of fluoride ions which was based on the decrease in color intensity of a ternary purple colored complex formed between thorium ions and bromocresol orange in the presence of fluoride ions.

A few years later, Arancibia et al. [104] proposed a flow system for the spectrophotometric fluoride determination in water samples, after its reaction with zirconium ions and 2-(parasulfophenylazo)-1,8-dihydroxy-3,6-naphthalene-disulfonate (SPADNS). Marques et al. [105] also used zirconium ions and SPADNS, aiming to reduce the consumption of reagents and to simplify data processing. The proposed method was rapid, amenable to automation, inexpensive, and environmentally friendly. The spectrophotometric determination of fluoride in trace amounts was based on the decolorization of a complex of $\mathrm{Al}(\mathrm{III})$ with xylenol orange as a color reagent characterized by high sensitivity, which was been proposed by Zolgharnein et al. [106]. In this approach, ascorbic acid was employed to overcome the interference of iron(III) ions.

Faraj-Zadeh and Kalhor [107] proposed an extraction-spectrophotometric method for the determination of fluoride ions in natural waters. For this purpose, octyl chemically bonded solid phase extraction (SPE) cartridge were employed and aluminum-oxinate chelates were initially adsorbed on the cartridges. Subsequently, the water samples that contained the fluoride ions passed through the SPE device. The oxine's excess was washed, the residual of aluminum-oxinate chelate was eluted, and its absorbance was measured at $375 \mathrm{~nm}$. The decrease of adsorbed aluminum-oxinate chelate was directly proportional to the concentration of the fuoride ions. The proposed method performed equally well with the Eriochrome cyanine R-zirconium standard method and better than the Alizarin complexon standard method. Moreover, less interferences were observed compared to the SPADNS standard method. Magnetic iron oxide nanoparticles have also been utilized for the SPE-spectrophotometric determination of fluoride in water. The proposed method was based on the discoloration of Fe(III)-SCN complex by the extracted fluoride ions, which was further monitored spectrophotometrically at $458 \mathrm{~nm}$. The proposed method was rapid, since the adsorption and desorption of fluoride could be completed within $5 \mathrm{~min}$ [102].

Barghouthi and Amereih [108] developed a spectrophotometric method for the determination of fluoride in drinking water using aluminum complexes of triphenylmethane dyes (chrome azurol $\mathrm{B}$ and malachite green) as spectrophotometric reagents. Fluoride reacts with the dark pink aluminum chrome azurol B complex and forms a colorless aluminum fluoride complex. As a result, there is a color change from dark pink to dark orange. Moreover, the absorbance of the aluminum complex at $425 \mathrm{~nm}$ increases when fluoride is present, while the absorbance at $581 \mathrm{~nm}$ decreases. Regarding the aluminum malachite green complex, fluoride can decrease its absorbance at $622 \mathrm{~nm}$. It was concluded that the aluminum chrome azurol B complex can be used as a sensitive reagent, albeit with low selectivity, while the aluminum malachite green complex can be used as a fluoride reagent at concentrations above $1.5 \times 10^{-5} \mathrm{M}$. The same authors [109] developed a simple test kit for the determination of fluoride in drinking water using a polymeric aluminum complex of 5-(2-carboxyphenylazo)-8-hydroxyquinoline impregnated paper, utilizing a small hand-held Arsenator instrument. The reaction of fluoride with the complex on an impregnated paper caused a color change due to the release of the free ligand with red 
color, which is related to fluoride's concentration. Subsequently, the Arsenator instrument was used for the photometric measurement of the reagent paper.

Although most of the atomic and molecular absorption spectrometry can exhibit high selectivity and sensitivity, the cost of these techniques is high (e.g., compared to electrochemical methods) [36].

\subsection{Microfluidic Methods}

FIA is a well-established automated analytical technique introduced by Ruzicka and Hansen [110]. It involves the injection of a sample into a moving stream of a solution (carrier) and propels the sample zone to a flowthrough detector. After the injection, and prior to its detection, the target analyte becomes detectable. FIA is considered as a simple and economic technique with good precision and versatility [111]. FIA coupled with various detection systems including ion-selective electrodes [112], spectrophotometry [113], spectrofluorometry [114-116], and ICP-OES [117] among others has been proposed for the determination of fluoride in water samples.

SIA analysis is a sample handling and manipulation technique that was invented by Ruzicka and Marshall in 1990 [118] in order to overcome some limitations of on-line approaches such as FIA. In SIA, a multi-position selection valve is employed, the common port of which is typically connected to holding coil. Its selection ports can be connected to various flow-through modules. Sample aspiration is performed, followed by storing in the coil, where it can be further processed [119]. Alpizar et al. used SIA for the simultaneous determination of chloride and fluoride ions in water samples. In this approach, ion-selective electrodes in in two serial flow-through cells were employed for the detection of target analytes. (see Table 3.)

Table 3. Sensors for the determination of fluoride in drinking water.

\begin{tabular}{|c|c|c|c|c|c|}
\hline Reagent & Method & Application & Linear Range & LOD & Ref. \\
\hline $\begin{array}{l}\text { 7-O-tert-butyldiphenylsilyl-4- } \\
\text { methylcoumarin }\end{array}$ & Fluorescence & $\begin{array}{l}\text { Surface and } \\
\text { ground water }\end{array}$ & $0.2-10 \mathrm{mg} \mathrm{L}^{-1}$ & $0.2 \mathrm{mg} \mathrm{L}^{-1}$ & [2] \\
\hline $\begin{array}{l}\text { Hydroxyl-decorated coumarin } \\
\text { connected with the bulky } \\
\text { tert-butyldiphenyloxysilyl group }\end{array}$ & Fluorescence & Drinking water & $0-9.15 \mathrm{mg} \mathrm{L}^{-1}$ & $0.043 \mathrm{mg} \mathrm{L}^{-1}$ & [120] \\
\hline $\begin{array}{l}\text { 2-hydroxy-1-naphthalene } \\
\text { formaldehyde }\end{array}$ & Fluorescence & Drinking water & $0-50$ equiv & $1.4 \times 10^{-8} \mathrm{M}$ & [121] \\
\hline $\begin{array}{c}\text { Silyl capped } \\
\text { hydroxylpyrenealdehyde }\end{array}$ & $\begin{array}{l}\text { Colorimetric and } \\
\text { Fluorescence }\end{array}$ & $\begin{array}{l}\text { Drinking water } \\
\text { and toothpaste }\end{array}$ & $\begin{array}{c}0-50 \mu \mathrm{M} \text { and } \\
50-250 \mu \mathrm{M}\end{array}$ & $2.7 \mu \mathrm{g} \mathrm{L}^{-1}$ & [50] \\
\hline Iron (III) thiocyanate & Colorimetric & Drinking water & - & - & [122] \\
\hline $\begin{array}{l}\text { Naphthalene-benzothiazole as } \\
\text { the fluorophore and } \\
\text { tert-butyldimethylsilyl as the } \\
\text { reactive groups (Sensor 1) } \\
\text { Naphthalene-benzothiazole as } \\
\text { the fluorophore and } \\
\text { tert-butyldiphenylsilyl as the } \\
\text { reactive groups (Sensor 2) }\end{array}$ & Fluorescence & Drinking water & $\begin{array}{c}0-6 \mu \mathrm{M} \text { (Sensor 1) } \\
0-40 \mu \mathrm{M} \text { (Sensor 2) }\end{array}$ & $\begin{array}{l}73 \mathrm{nM} \\
\text { (Sensor 1) } \\
138 \mathrm{nM} \\
\text { (Sensor 2) }\end{array}$ & [123] \\
\hline Nitrogen-doped GO & Fluorescence & Water & - & $1 \times 10^{-12} \mathrm{M}$ & [124] \\
\hline Zirconium-SPADNS & Colorimetric & Ground water & $0.2-2 \mathrm{mg} \mathrm{L}^{-1}$ & $0.2 \mathrm{mg} \mathrm{L}^{-1}$ & {$[35]$} \\
\hline $\begin{array}{c}\text { Near-cubic ceria@ zirconia } \\
\text { nanocages) and a xylenol }\end{array}$ & Colorimetric & Field water & $0.1-5 \mathrm{mg} \mathrm{L}^{-1}$ & $0.06 \mathrm{mg} \mathrm{L}^{-1}$ & [125] \\
\hline
\end{tabular}




\subsection{Sensors}

Although some of the aforementioned analytical techniques (e.g., spectroscopy, ionic chromatography etc.) are currently well-established and widely used for the determination of fluoride in drinking water, a considerable effort has been made recently to design chemosensors for anions. Chemical sensors typically comprise of a receptor unit and a signaling unit. Chromogenic (or colorimetric) sensing and fluorogenic sensing have been widely used for the determination of fluoride. Chromogenic sensing employs a signaling unit of a sensor that contains chromophores, while fluorogenic sensing employs a signaling unit of a sensor that contains fluorophores [126]. Table 3 presents the applications of sensing systems for the determination of fluoride in drinking water that were published after 2015 [124].

Over the past years, there has been a large number of colorimetric and fluorescence sensors that have been developed and applied to monitor the water quality and to determine the concentration of fluoride ions. Most of these systems are based on the interactions of the anions with Lewis acids [2]. Typical examples of systems for the determination of fluoride in drinking water include sensors with fluorene and triazolium units [127], 2-hydroxy -1-naphthalene formaldehyde [121], silyl capped hydroxylpyrenealdehyde [128], imidazole moieties [129], boron-containing $\pi$-electron systems [130], silyl ether groups [131], coumarin groups [120], etc. Sensors that have been developed based on the supramolecular chemistry approach are also important tools for the fluoride's detection. These materials can show good affinity and selectivity for ion sensing [132]. An example of these materials was presented by Aydogan et al. [133]. The authors presented a functionalized calix [4] pyrrole compound as an effective electrochemical sensing system for the detection of fluoride in water.

Systems taking advantage of silyl-ether-fluoride interactions have shown great potential for fluoride sensing because of the high affinity of silyl groups towards fluoride [2].

Chavali et al. [2] reported the development of a rapid method for the detection of fluoride in potable water using a novel fluorogenic compound 7-O-tert-butyldiphenylsilyl4-methylcoumarin. This compound is colorless. However, it releases fluorescent molecules imparting blue fluorescence to the solution when interacting with fluoride ions in water. Hand-held UV lamps were employed for visualization of the blue fluorescence. The proposed sensor can be easily field deployable, it is rapid (sensing in 5-10 s), and it can be considered useful for monitoring water quality in communities with limited resources. A coumarin-based sensor has been also proposed for the selective detection of fluoride in drinking water [120]. In this case, the detection mechanism was based on a fluoridemediated desilylation triggering fluorogenic reaction and a strong interaction between fluoride and the silicon center of a hydroxyl-decorated coumarin connected with the bulky tert-butyldiphenyloxysilyl group. The proposed sensor exhibited both satisfactory accuracy and limit of detection (LOD) for fluoride. Lin et al. [121] developed a colorimetric and turnon fluorescent sensor for fluoride ions, based on a 2-hydroxy -1-naphthalene formaldehyde bis-Schiff base. In the presence of fluoride ions, a color change from pale yellow to deep yellow and a prominent fluorescence enhancement occurred due to hydrogen bonding and deprotonation in the sensor. Rapid detection was allowed, since less than $1 \mathrm{~s}$ was required for the response of the sensor. Finally, test strips were developed, showing low LOD for fluoride ions. A colorimetric and ratiometric fluorescence sensor based on silyl capped hydroxylpyrenealdehyde that detects fluoride through desilylation and spectral change of pyrene derivative has been also proposed [50]. A 255-fold enrichment was achieved that enabled the detection of fluoride at low concentrations in water and toothpaste samples.

Mandal et al. [122] developed paper sensors for the point-of-care monitoring of drinking water quality. In this case, the determination of fluoride was based on a specific reaction between fluoride ions and iron(III) thiocyanate. The utilization of paper as substrate enabled the fabrication of a sensing system with simplicity, low cost, and disposability. In order to determine the color variation on the paper, the sensors were illuminated with a light emitting diode (LED) on one side and with a light dependent resistor (LDR) on the 
other side. Monotonically variation of the LDR resistance was observed with the change of fluoride's concentration. Due to the presence of microchannels on the paper's surface, the immediate mixing of the reagents and the analyte was assisted through capillary actions, resulting in both a rapid chemical reaction and response.

Wu et al. [123] developed two sensitive and ratiometric fluorescence test paper sensors for the determination of fluoride ions in water samples. The first probe was prepared using naphthalene-benzothiazole as the fluorophore, tert-butyldimethylsilyl as the reactive groups, and the $\mathrm{Si}-\mathrm{O}$ bond as the reaction site. The second probe was prepared using naphthalene-benzothiazole as the fluorophore, tert-butyldiphenylsilyl as the reactive groups, and the $\mathrm{Si}-\mathrm{O}$ bond as the reaction site. The linear range of the first probe ranged between 0 and $6 \mu \mathrm{M}$, and its LOD was found to be $73 \mathrm{nM}$, while the linear range of the second probe ranged between 0 and $40 \mu \mathrm{M}$ and its LOD was found to be $138 \mathrm{nM}$. As a result, the first sensor was proposed for the monitoring of the water safety level regarding fluoride's concentration, while the second sensor can be employed if its concentration surpasses dangerously high levels. The test paper sensors were simple and convenient for determining whether or not the quality of the water samples meets the appropriate standards for drinking water.

Novel materials, including metal-organic frameworks (MOFs) [134] and GO [124] have also been employed to develop sensors for the determination of fluoride. The metal-organic framework $\mathrm{NH}_{2}-\mathrm{MIL}-101(\mathrm{Al})$, prepared from 2-amino terephthalic acid and aluminum (III) chloride hexahydrate, was employed to prepare a sensor for the determination of fluoride in water through fluorophore release. In this approach, the detection of fluoride anions was achieved through complexation induced decomposition of the MOF that resulted in the release of the fluorescent dye molecule. As a result, high sensitivity and selectivity was reported [134]. A few years later, nitrogen-doped GO was also employed for the fabrication of a sensing system for fluoride anions. In this case, the nitrogen-doped GO served both as a substrate and as a fluorogenic probe after its fluorescence was completely quenched by iron (III) ions. The quenched fluorescence of the sensor was turned in presence of fluoride ions, enabling its sensitive visual detection through testing-paper.

Smartphone-based sensors have also been developed for the determination of fluoride in water samples. Hussain et al. [35] developed a low cost, field portable smartphone platform fluoride sensor by utilizing the ambient light sensor of the smartphone as a light intensity detector and its LED flash light as an optical source. Fluoride's detection was based on the standard SPADNS colorimetric method, in which fluoride ions can react with zirconium dyes to form colorless complex anions. The researchers also developed an android application for the determination of fluoride concentration in water samples. The proposed application could share the data from in-field sensing in remote locations to the monitoring station that is responsible for water quality.

In 2020, Mukherjee et al. [125] developed a smartphone-based fluoride-specific sensor. For this purpose, a simple smartphone attachment was developed for colorimetric readout using a combination of a light-emitting diode (LED) and a photodiode that facilitates precise measurement of fluoride ions. The novel hand-held mobile device is cheap, and allows for the fast and sensitive colorimetric detection of fluoride ions by utilizing core-shell nanoparticles (near-cubic ceria@ zirconia nanocages) and xylenol orange as a chemoresponsive dye.

Sensors are typically simple and cost-effective devices which are powerful tools for the direct determination of fluoride, overcoming the need for sample transporting. Thus, they are an important option for fluoride detection in developing countries.

\section{Conclusions}

This review article presents the recently developed adsorbents for fluoride removal and advances in analytical determination in drinking water. The major findings are listed in the following points: 
- The modification of activated carbon with metal oxides and hydroxides was found to effectively remove fluoride from water, providing adsorption capacities of up to $25 \mathrm{mg} \mathrm{g}^{-1}$ for the case of $\mathrm{Zr}-\mathrm{ACF}$ and $220.5 \mathrm{mg} \mathrm{g}^{-1}$ for $\mathrm{La} / \mathrm{Mg} / \mathrm{Si}-\mathrm{AC}$.

- Similarly, graphene oxide modification enhanced significantly the adsorbing efficiency, exhibiting ever higher adsorption capacities than those achieved with modified activated carbon which, in the case of ZIGCS, reached $175 \mathrm{mg} \mathrm{g}^{-1}$.

- The use of $\mathrm{MgO}$ nanostructures exhibited a maximum Langmuir adsorption capacity of $29,131 \mathrm{mg} \mathrm{g}^{-1}$, which is the highest for any adsorbent reported till now for the development of fluoride adsorbents.

- Regeneration experiments can be performed, provided that all the materials can be recycled from three to six cycles.

- Al materials reported are effective in the $\mathrm{pH}$ range relevant to drinking water treatment (i.e., 6-8).

Regarding the analytical determination techniques for fluoride, the major findings are as follows:

- Ion-selective electrodes, spectrometry, ionic chromatography, etc., are considered as well-established and are widely used.

- The development of new methodologies that can selectively, accurately, and rapidly detect fluoride is of paramount importance and, thus, is still in the forefront of research.

- Currently, a plethora of promising sensing systems that take advantage of the technological progress of our times (e.g., the development of smartphone-based sensors) are gaining more and more popularity.

Author Contributions: Conceptualization, A.K.T., N.M., G.A.Z., I.A.K. and E.A.D.; investigation, A.K.T. and N.M.; writing-original draft preparation, A.K.T., N.M.; writing-review and editing, A.K.T., N.M., G.A.Z., I.A.K. and E.A.D.; supervision, G.A.Z., I.A.K. and E.A.D. All authors have read and agreed to the published version of the manuscript.

Funding: This research received no external funding.

Institutional Review Board Statement: Not applicable.

Informed Consent Statement: Not applicable.

Data Availability Statement: Not applicable.

Conflicts of Interest: The authors declare no conflict of interest.

\section{References}

1. Barghouthi, Z.; Amereih, S. Spectrophotometric Determination of Fluoride in Groundwater Using Resorcin Blue Complexes. Am. J. Anal. Chem. 2012, 3, 651-655. [CrossRef]

2. Chavali, R.; Gunda, N.S.K.; Naicker, S.; Mitra, S.K. Rapid detection of fluoride in potable water using a novel fluorogenic compound 7-O-tert-butyldiphenylsilyl-4-methylcoumarin. Anal. Chem. Res. 2015, 6, 26-31. [CrossRef]

3. Premathilaka, R.W.; Liyanagedera, N.D. Fluoride in Drinking Water and Nanotechnological Approaches for Eliminating Excess Fluoride. J. Nanotechnol. 2019, 2019, 1-15. [CrossRef]

4. Arya, S.; Subramani, T.; Vennila, G.; Karunanidhi, D. Health risks associated with fluoride intake from rural drinking water supply and inverse mass balance modeling to decipher hydrogeochemical processes in Vattamalaikarai River basin, South India. Environ. Geochem. Health 2021, 43, 705-716. [CrossRef]

5. Singh, J.; Singh, P.; Singh, A. Fluoride ions vs removal technologies: A study. Arab. J. Chem. 2016, 9, 815-824. [CrossRef]

6. Grönwall, J.; Danert, K. Regarding Groundwater and Drinking Water Access through A Human Rights Lens: Self-Supply as A Norm. Water 2020, 12, 419. [CrossRef]

7. Yadav, K.K.; Kumar, S.; Pham, Q.B.; Gupta, N.; Rezania, S.; Kamyab, H.; Yadav, S.; Vymazal, J.; Kumar, V.; Tri, D.Q.; et al. Fluoride contamination, health problems and remediation methods in Asian groundwater: A comprehensive review. Ecotoxicol. Environ. Saf. 2019, 182, 109362. [CrossRef] [PubMed]

8. Ndé-Tchoupé, A.I.; Tepong-Tsindé, R.; Lufingo, M.; Pembe-Ali, Z.; Lugodisha, I.; Mureth, R.I.; Nkinda, M.; Marwa, J.; Gwenzi, W.; Mwamila, T.B.; et al. White Teeth and Healthy Skeletons for All: The Path to Universal Fluoride-Free Drinking Water in Tanzania. Water 2019, 11, 131. [CrossRef] 
9. Rasool, A.; Farooqi, A.; Xiao, T.; Ali, W.; Noor, S.; Abiola, O.; Ali, S.; Nasim, W. A review of global outlook on fluoride contamination in groundwater with prominence on the Pakistan current situation. Environ. Geochem. Health 2018, 40, $1265-1281$. [CrossRef]

10. Wang, H.; He, H.; Wang, H.; Zhou, Z.; Yu, C. Trends of fluoride control in China. Environ. Earth Sci. 2019, 78, 580. [CrossRef]

11. Kisku, G.C.; Sahu, P. Fluoride Contamination and Health Effects: An Indian Scenario. Environ. Concerns Sustain. Dev. 2019, 213-233. [CrossRef]

12. Yadav, K.K.; Gupta, N.; Kumar, V.; Khan, S.; Kumar, A. A review of emerging adsorbents and current demand for defluoridation of water: Bright future in water sustainability. Environ. Int. 2018, 111, 80-108. [CrossRef] [PubMed]

13. He, Z.; Liu, R.; Xu, J.; Liu, H.; Qu, J. Defluoridation by Al-based coagulation and adsorption: Species transformation of aluminum and fluoride. Sep. Purif. Technol. 2015, 148, 68-75. [CrossRef]

14. Gong, W.-X.; Qu, J.-H.; Liu, R.-P.; Lan, H.-C. Effect of aluminum fluoride complexation on fluoride removal by coagulation. Colloids Surf. A Physicochem. Eng. Asp. 2012, 395, 88-93. [CrossRef]

15. Tolkou, A.K.; Mitrakas, M.; Katsoyiannis, I.A.; Ernst, M.; Zouboulis, A.I. Fluoride removal from water by composite $\mathrm{Al} / \mathrm{Fe} / \mathrm{Si} / \mathrm{Mg}$ pre-polymerized coagulants: Characterization and application. Chemosphere 2019, 231, 528-537. [CrossRef]

16. Alhassan, S.I.; Huang, L.; He, Y.; Yan, L.; Wu, B.; Wang, H. Fluoride removal from water using alumina and aluminum-based composites: A comprehensive review of progress. Crit. Rev. Environ. Sci. Technol. 2020, 2020, 1-35. [CrossRef]

17. Jagtap, S.; Yenkie, M.K.; Labhsetwar, N.; Rayalu, S. Fluoride in Drinking Water and Defluoridation of Water. Chem. Rev. 2012, 112, 2454-2466. [CrossRef]

18. Kumar, P.S.; Suganya, S.; Srinivas, S.; Priyadharshini, S.; Karthika, M.; Sri, R.K.; Swetha, V.; Naushad, M.; Lichtfouse, E. Treatment of fluoride-contaminated water. A review. Environ. Chem. Lett. 2019, 17, 1707-1726. [CrossRef]

19. Van der Bruggen, B.; Mänttäri, M.; Nyström, M. Drawbacks of applying nanofiltration and how to avoid them: A review. Sep. Purif. Technol. 2008, 63, 251-263. [CrossRef]

20. Fito, J.; Said, H.; Feleke, S.; Worku, A. Fluoride removal from aqueous solution onto activated carbon of Catha edulis through the adsorption treatment technology. Environ. Syst. Res. 2019, 8, 1-10. [CrossRef]

21. Zarrabi, M.; Samadi, M.T.; Sepehr, M.N.; Ramhormozi, S.M.; Azizian, S.; Amrane, A. Removal of Fluoride Ions by Ion Exchange Resin: Kinetic and Equilibrium Studies. Environ. Eng. Manag. J. 2014, 13, 205-214. [CrossRef]

22. Prabhu, S.M.; Meenakshi, S. Synthesis of metal ion loaded silica gel/chitosan biocomposite and its fluoride uptake studies from water. J. Water Process. Eng. 2014, 3, 144-150. [CrossRef]

23. Varaprasad, K.; Nunez, D.; Yallapu, M.M.; Jayaramudu, T.; Elgueta, E.; Oyarzun, P. Nano-hydroxyapatite polymeric hydrogels for dye removal. RSC Adv. 2018, 8, 18118-18127. [CrossRef] [PubMed]

24. Tor, A.; Danaoglu, N.; Arslan, G.; Cengeloglu, Y. Removal of fluoride from water by using granular red mud: Batch and column studies. J. Hazard. Mater. 2009, 164, 271-278. [CrossRef]

25. Kemer, B.; Ozdes, D.; Gundogdu, A.; Bulut, V.N.; Duran, C.; Soylak, M. Removal of fluoride ions from aqueous solution by waste mud. J. Hazard. Mater. 2009, 168, 888-894. [CrossRef] [PubMed]

26. Fujita, S.; Suzuki, A. Electrical Conduction in Graphene and Nanotubes; John Wiley \& Sons: Hoboken, NJ, USA, 2013; ISBN 9783527411.

27. Geethamani, C.; Ramesh, S.; Gandhimathi, R.; Nidheesh, P. Alkali-treated fly ash for the removal of fluoride from aqueous solutions. Desalination Water Treat. 2013, 52, 3466-3476. [CrossRef]

28. Delgadillo-Velasco, L.; Hernández-Montoya, V.; Cervantes, F.J.; Montes-Morán, M.A.; Lira-Berlanga, D. Bone char with antibacterial properties for fluoride removal: Preparation, characterization and water treatment. J. Environ. Manag. 2017, 201, 277-285. [CrossRef] [PubMed]

29. Ndé-Tchoupé, A.I.; Nanseu-Njiki, C.P.; Hu, R.; Nassi, A.; Noubactep, C.; Licha, T. Characterizing the reactivity of metallic iron for water defluoridation in batch studies. Chemosphere 2019, 219, 855-863. [CrossRef]

30. Khandare, D.; Mukherjee, S. A Review of Metal oxide Nanomaterials for Fluoride decontamination from Water Environment. Mater. Today Proc. 2019, 18, 1146-1155. [CrossRef]

31. Suriyaraj, S.P.; Selvakumar, R. Advances in nanomaterial based approaches for enhanced fluoride and nitrate removal from contaminated water. RSC Adv. 2016, 6, 10565-10583. [CrossRef]

32. Yahyavi, H.; Kaykhaii, M.; Mirmoghaddam, M. Recent Developments in Methods of Analysis for Fluoride Determination. Crit. Rev. Anal. Chem. 2015, 46, 106-121. [CrossRef]

33. Radić, J.; Bralić, M.; Kolar, M.; Genorio, B.; Prkić, A.; Mitar, I. Development of the New Fluoride Ion-Selective Electrode Modified with $\mathrm{Fe}_{\mathrm{x}} \mathrm{O}_{\mathrm{y}}$ Nanoparticles. Molecules 2020, 25, 5213. [CrossRef] [PubMed]

34. Hussain, I.; Ahamad, K.U.; Nath, P. Low-Cost, Robust, and Field Portable Smartphone Platform Photometric Sensor for Fluoride Level Detection in Drinking Water. Anal. Chem. 2016, 89, 767-775. [CrossRef] [PubMed]

35. Mohapatra, M.; Anand, S.; Mishra, B.; Giles, D.E.; Singh, P. Review of fluoride removal from drinking water. J. Environ. Manag. 2009, 91, 67-77. [CrossRef]

36. Bhatnagar, A.; Kumar, E.; Sillanpää, M. Fluoride removal from water by adsorption-A review. Chem. Eng. J. 2011, 171, 811-840. [CrossRef]

37. Dhillon, A.; Nair, M.; Kumar, D. Analytical methods for determination and sensing of fluoride in biotic and abiotic sources: A review. Anal. Methods 2016, 8, 5338-5352. [CrossRef] 
38. Jin, H.; Ji, Z.; Yuan, J.; Li, J.; Liu, M.; Xu, C.; Dong, J.; Hou, P.; Hou, S. Research on removal of fluoride in aqueous solution by alumina-modified expanded graphite composite. J. Alloys Compd. 2015, 620, 361-367. [CrossRef]

39. Larsen, M.; Pearce, E.; Ravnholt, G. The effectiveness of bone char in the defluoridation of water in relation to its crystallinity, carbon content and dissolution pattern. Arch. Oral Biol. 1994, 39, 807-816. [CrossRef]

40. Kennedy, A.M.; Arias-Paic, M. Fixed-Bed Adsorption Comparisons of Bone Char and Activated Alumina for the Removal of Fluoride from Drinking Water. J. Environ. Eng. 2020, 146, 04019099. [CrossRef]

41. Alkurdi, S.S.; Al-Juboori, R.A.; Bundschuh, J.; Hamawand, I. Bone char as a green sorbent for removing health threatening fluoride from drinking water. Environ. Int. 2019, 127, 704-719. [CrossRef]

42. Nigri, E.M.; Santos, A.L.A.; Bhatnagar, A.; Rocha, S.D.F. Chemical Regeneration of Bone Char Associated With A Continuous System for Defluoridation of Water. Braz. J. Chem. Eng. 2019, 36, 1631-1643. [CrossRef]

43. Nigri, E.M.; Bhatnagar, A.; Rocha, S.D.F. Thermal regeneration process of bone char used in the fluoride removal from aqueous solution. J. Clean. Prod. 2017, 142, 3558-3570. [CrossRef]

44. Kanouo, B.M.D.; Fonteh, M.F.; Ngambo, S.P. Development of a low cost household bone-char defluoridation filter. Int. J. Biol. Chem. Sci. 2020, 14, 1921-1927. [CrossRef]

45. Collivignarelli, M.C.; Abbà, A.; Miino, M.C.; Torretta, V.; Rada, E.C.; Caccamo, F.M.; Sorlini, S. Adsorption of Fluorides in Drinking Water by Palm Residues. Sustainability 2020, 12, 3786. [CrossRef]

46. Herath, H.M.A.S.; Kawakami, T.; Tafu, M. The Extremely High Adsorption Capacity of Fluoride by Chicken Bone Char (CBC) in Defluoridation of Drinking Water in Relation to Its Finer Particle Size for Better Human Health. Healthcares 2018, 6, 123. [CrossRef] [PubMed]

47. Kikuchi, M.; Arioka, Y.; Tafu, M.; Irie, M. Changes in fluoride removal ability of chicken bone char with changes in calcination time. Int. J. Ceram. Eng. Sci. 2020, 2, 83-91. [CrossRef]

48. AlOthman, Z.A.; Habila, M.; Ali, R.; Ghafar, A.A.; El-din Hassounab, M.S. Valorization of two waste streams into activated carbon and studying its adsorption kinetics, equilibrium isotherms and thermodynamics for methylene blue removal. Arab. J. Chem. 2014, 7, 1148-1158. [CrossRef]

49. Gallios, G.P.; Tolkou, A.K.; Katsoyiannis, I.A.; Stefusova, K.; Vaclavikova, M.; Deliyanni, E.A. Adsorption of Arsenate by Nano Scaled Activated Carbon Modified by Iron and Manganese Oxides. Sustainability 2017, 9, 1684. [CrossRef]

50. Li, Y.; Zhang, C.; Jiang, Y.; Wang, T.-J. Electrically enhanced adsorption and green regeneration for fluoride removal using $\mathrm{Ti}(\mathrm{OH}) 4-$ loaded activated carbon electrodes. Chemosphere 2018, 200, 554-560. [CrossRef] [PubMed]

51. Pang, T.; Chan, T.S.A.; Jande, Y.A.C.; Shen, J. Removal of fluoride from water using activated carbon fibres modified with zirconium by a drop-coating method. Chemosphere 2020, 255, 126950. [CrossRef] [PubMed]

52. Li, Y.-H.; Di, Z.; Ding, J.; Wu, D.; Luan, Z.; Zhu, Y. Adsorption thermodynamic, kinetic and desorption studies of Pb2+ on carbon nanotubes. Water Res. 2005, 39, 605-609. [CrossRef]

53. Khan, Z.H.; Gao, M.; Qiu, W.; Islam, S.; Song, Z. Mechanisms for cadmium adsorption by magnetic biochar composites in an aqueous solution. Chemosphere 2020, 246, 125701. [CrossRef]

54. Gao, H.; Kan, T.; Zhao, S.; Qian, Y.; Cheng, X.; Wu, W.; Wang, X.; Zheng, L. Removal of anionic azo dyes from aqueous solution by functional ionic liquid cross-linked polymer. J. Hazard. Mater. 2013, 261, 83-90. [CrossRef] [PubMed]

55. Tefera, N.; Mulualem, Y.; Fito, J. Adsorption of Fluoride from Aqueous Solution and Groundwater onto Activated Carbon of Avocado Seeds. Water Conserv. Sci. Eng. 2020, 5, 187-197. [CrossRef]

56. Dehghani, M.H.; Farhang, M.; Alimohammadi, M.; Afsharnia, M.; McKay, G. Adsorptive removal of fluoride from water by activated carbon derived from $\mathrm{CaCl}$-modified Crocus sativus leaves: Equilibrium adsorption isotherms, optimization, and influence of anions. Chem. Eng. Commun. 2018, 205, 955-965. [CrossRef]

57. Kim, M.; Choong, C.E.; Hyun, S.; Park, C.M.; Lee, G. Mechanism of simultaneous removal of aluminum and fluoride from aqueous solution by $\mathrm{La} / \mathrm{Mg} / \mathrm{Si}$-activated carbon. Chemosphere 2020, 253, 126580. [CrossRef] [PubMed]

58. Lin, Y.-J.; Cao, W.-Z.; Ouyang, T.; Mohan, S.; Chang, C.-T. Adsorption mechanism of magnetic nanoparticles doped with graphene oxide and titanium nanotubes for As(III) removal. Materialia 2018, 3, 79-89. [CrossRef]

59. Molla, A.; Li, Y.; Mandal, B.; Kang, S.G.; Hur, S.H.; Chung, J.S. Selective adsorption of organic dyes on graphene oxide: Theoretical and experimental analysis. Appl. Surf. Sci. 2019, 464, 170-177. [CrossRef]

60. Liu, H.; Zhang, F.; Peng, Z. Adsorption mechanism of Cr(VI) onto GO/PAMAMs composites. Sci. Rep. 2019, 9, 1-12. [CrossRef] [PubMed]

61. Tolkou, A.K.; Zouboulis, A.I. Graphene Oxide/Fe-Based Composite Pre-Polymerized Coagulants: Synthesis, Characterization, and Potential Application in Water Treatment. C J. Carbon Res. 2020, 6, 44. [CrossRef]

62. Guan, C.; Lv, X.; Han, Z.; Chen, C.; Xu, Z.; Liu, Q. The adsorption enhancement of graphene for fluorine and chlorine from water. Appl. Surf. Sci. 2020, 516, 146157. [CrossRef]

63. Xu, N.; Li, S.; Li, W.; Liu, Z. Removal of Fluoride by Graphene Oxide/Alumina Nanocomposite: Adsorbent Preparation, Characterization, Adsorption Performance and Mechanisms. ChemistrySelect 2020, 5, 1818-1828. [CrossRef]

64. Barathi, M.; Kumar, S.K.; Kumar, C.U.; Rajesh, N.P. Graphene oxide-aluminium oxyhydroxide interaction and its application for the effective adsorption of fluoride. RSC Adv. 2014, 4, 53711-53721. [CrossRef]

65. Nor, N.M.; Kamil, N.H.N.; Mansor, A.I.; Maarof, H.I. Adsorption Analysis of Fluoride Removal Using Graphene Oxide/Eggshell Adsorbent. Indones. J. Chem. 2020, 20, 579-586. [CrossRef] 
66. Prathibha, C.; Biswas, A.; Chunduri, L.A.; Reddy, S.K.; Loganathan, P.; Kalaruban, M.; Venkatarmaniah, K. Zr(IV) functionalized graphene oxide anchored sand as potential and economic adsorbent for fluoride removal from water. Diam. Relat. Mater. 2020, 109, 108081. [CrossRef]

67. Ruan, Z.; Tian, Y.; Ruan, J.; Cui, G.; Iqbal, K.; Iqbal, A.; Ye, H.; Yang, Z.; Yan, S. Synthesis of hydroxyapatite/multi-walled carbon nanotubes for the removal of fluoride ions from solution. Appl. Surf. Sci. 2017, 412, 578-590. [CrossRef]

68. Pillai, P.; Dharaskar, S.; Shah, M.; Sultania, R. Determination of fluoride removal using silica nano adsorbent modified by rice husk from water. Groundw. Sustain. Dev. 2020, 11, 100423. [CrossRef]

69. Jeyaseelan, A.; Naushad, M.; Ahamad, T.; Viswanathan, N. Design and development of amine functionalized iron based metal organic frameworks for selective fluoride removal from water environment. J. Environ. Chem. Eng. 2021, 9, 104563. [CrossRef]

70. Annan, E.; Nyankson, E.; Agyei-Tuffour, B.; Armah, S.K.; Nkrumah-Buandoh, G.; Hodasi, J.A.M.; Oteng-Peprah, M. Synthesis and Characterization of Modified Kaolin-Bentonite Composites for Enhanced Fluoride Removal from Drinking Water. Adv. Mater. Sci. Eng. 2021, 2021, 1-12. [CrossRef]

71. Vences-Alvarez, E.; Flores-Arciniega, J.L.; Flores-Zuñiga, H.; Rangel-Mendez, J.R. Fluoride removal from water by ceramic oxides from cerium and manganese solutions. J. Mol. Liq. 2019, 286, 110880. [CrossRef]

72. Borgohain, X.; Boruah, A.; Sarma, G.K.; Rashid, H. Rapid and extremely high adsorption performance of porous MgO nanostructures for fluoride removal from water. J. Mol. Liq. 2020, 305, 112799. [CrossRef]

73. He, Y.; Zhang, L.; An, X.; Wan, G.; Zhu, W.; Luo, Y. Enhanced fluoride removal from water by rare earth (La and Ce) modified alumina: Adsorption isotherms, kinetics, thermodynamics and mechanism. Sci. Total Environ. 2019, 688, 184-198. [CrossRef]

74. Pillai, P.; Dharaskar, S.; Sinha, M.K.; Sillanpää, M.; Khalid, M. Iron oxide nanoparticles modified with ionic liquid as an efficient adsorbent for fluoride removal from groundwater. Environ. Technol. Innov. 2020, 19, 100842. [CrossRef]

75. Roy, A. Microwave-assisted synthesis and characterization of $\gamma$-Al2O3/ $\gamma$-Fe2O 3 composite and evaluating its efficiency in fluoride removal. Colloids Surf. A Physicochem. Eng. Asp. 2021, 608, 125574. [CrossRef]

76. Tan, T.L.; Krusnamurthy, P.A.; Nakajima, H.; Rashid, S.A. Adsorptive, kinetics and regeneration studies of fluoride removal from water using zirconium-based metal organic frameworks. RSC Adv. 2020, 10, 18740-18752. [CrossRef]

77. Wang, Z.; Su, J.; Hu, X.; Ali, A.; Wu, Z. Isolation of biosynthetic crystals by microbially induced calcium carbonate precipitation and their utilization for fluoride removal from groundwater. J. Hazard. Mater. 2021, 406, 124748. [CrossRef]

78. Mesbah, M.; Hamedshahraki, S.; Ahmadi, S.; Sharifi, M.; Igwegbe, C.A. Hydrothermal synthesis of LaFeO3 nanoparticles adsorbent: Characterization and application of error functions for adsorption of fluoride. MethodsX 2020, 7, 100786. [CrossRef] [PubMed]

79. Al-Ghouti, M.A.; Al-Absi, R.S. Mechanistic understanding of the adsorption and thermodynamic aspects of cationic methylene blue dye onto cellulosic olive stones biomass from wastewater. Sci. Rep. 2020, 10, 1-18. [CrossRef] [PubMed]

80. Thomas, J.M. The existence of endothermic adsorption. J. Chem. Educ. 1961, 38, 138. [CrossRef]

81. Lupo, M.; Fina, B.L.; Aguirre, M.C.; Armendariz, M.; Rigalli, A. Determination of Water Fluoride Concentration and the Influence of the Geographic Coordinate System and Time. Water Air Soil Pollut. 2012, 223, 5221-5225. [CrossRef]

82. El Jaoudi, R.; Mamouch, F.; El Cadi, M.A.; Bousliman, Y.; Cherrah, Y.; Bouklouze, A. Determination of Fluoride in Tap Water in Morocco using a Direct Electrochemical Method. Bull. Environ. Contam. Toxicol. 2012, 89, 390-394. [CrossRef] [PubMed]

83. Yuchi, A.; Matsunaga, K.; Niwa, T.; Terao, H.; Wada, H. Separation and preconcentration of fluoride at the ngml-1 level with a polymer complex of zirconium(IV) followed by potentiometric determination in a flow system. Anal. Chim. Acta 1999, 388, 201-208. [CrossRef]

84. Hosseini, M.S.; Rahiminegad, H. Potentiometric determination of ultratrace amounts of fluoride enriched by zirconia in a flow system. J. Anal. Chem. 2006, 61, 166-171. [CrossRef]

85. Ruiz-Payan, A.; Ortiz, M.; Duarte-Gardea, M. Determination of fluoride in drinking water and in urine of adolescents living in three counties in Northern Chihuahua Mexico using a fluoride ion selective electrode. Microchem. J. 2005, 81, 19-22. [CrossRef]

86. Van Staden, J.F.; Stefan, R.I. Simultaneous flow injection determination of calcium and fluoride in natural and borehole water with conventional ion-selective electrodes in series. Talanta 1999, 49, 1017-1022. [CrossRef]

87. Mao, Y.; Chen, Y.; Chu, L.; Zhang, X. Electrodeposited apatite coating for solid-phase microextraction and sensitive indirect voltammetric determination of fluoride ions. Talanta 2013, 115, 500-505. [CrossRef] [PubMed]

88. Guanghan, L.; Qiongling, W.; XiaoGang, W.; Tong, Z.; Xin, Y. Polarographic determination of trace fluoride in foods. Food Chem. 1999, 66, 519-523. [CrossRef]

89. Frant, M.S.; Ross, J.W. Electrode for Sensing Fluoride Ion Activity in Solution. Science 1966, 154, 1553-1555. [CrossRef]

90. Quintana, M.C.; Blanco, M.H.; Hernandez, L. Highly Sensitive Methods for Determination of Fluoride in Biological Samples. J. Liq. Chromatogr. Relat. Technol. 2003, 26, 763-772. [CrossRef]

91. Kaykhaii, M.; Dicinoski, G.W.; Haddad, P.R. Solid-Phase Microextraction for the Determination of Inorganic Ions: Applications and Possibilities. Anal. Lett. 2010, 43, 1546-1555. [CrossRef]

92. Jones, P. Development of a high-sensitivity ion chromatography method for the determination of trace fluoride in water utilizing the formation of the AlF2+ species. Anal. Chim. Acta 1992, 258, 123-127. [CrossRef]

93. Bayón, M.M.; Garcia, A.R.; Alonso, J.I.G.; Sanz-Medel, A. Indirect determination of trace amounts of fluoride in natural waters by ion chromatography: A comparison of on-line post-column fluorimetry and ICP-MS detectors. Analyst 1999, 124, 27-31. [CrossRef] [PubMed] 
94. Samanidou, V.F.; Zacharis, C.; Papadoyannis, I.N. Determination of Fluoride Ions by Single Column High Pressure Anion Chromatography in Dentifrice Preparations and Body Fluids: Saliva and Blood Serum. J. Liq. Chromatogr. Relat. Technol. 2002, 25, 803-818. [CrossRef]

95. Musijowski, J.; Szostek, B.; Koc, M.; Trojanowicz, M. Determination of fluoride as fluorosilane derivative using reversed-phase HPLC with UV detection for determination of total organic fluorine. J. Sep. Sci. 2010, 33, 2636-2644. [CrossRef]

96. Xu, X.R.; Li, H.B.; Gu, J.-D.; Paeng, K.J. Determination of Fluoride in Water by Reversed-Phase High-Performance Liquid Chromatography using F?-La3+-Alizarin Complexone Ternary Complex. Chromatographia 2004, 59, 745-747. [CrossRef]

97. Pagliano, E.; Meija, J.; Ding, J.; Sturgeon, R.E.; D’Ulivo, A.; Mester, Z. Novel Ethyl-Derivatization Approach for the Determination of Fluoride by Headspace Gas Chromatography/Mass Spectrometry. Anal. Chem. 2013, 85, 877-881. [CrossRef]

98. Gleisner, H.; Welz, B.; Einax, J.W. Optimization of fluorine determination via the molecular absorption of gallium mono-fluoride in a graphite furnace using a high-resolution continuum source spectrometer. Spectrochim. Acta Part B At. Spectrosc. 2010, 65, 864-869. [CrossRef]

99. Huang, M.D.; Becker-Ross, H.; Florek, S.; Heitmann, U.; Okruss, M. Determination of halogens via molecules in the air-acetylene flame using high-resolution continuum source absorption spectrometry: Part I. Fluorine. Spectrochim. Acta Part B At. Spectrosc. 2006, 61, 572-578. [CrossRef]

100. Heitmann, U.; Becker-Ross, H.; Florek, S.; Huang, M.D.; Okruss, M. Determination of non-metals via molecular absorption using high-resolution continuum source absorption spectrometry and graphite furnace atomization. J. Anal. At. Spectrom. 2006, 21, 1314-1320. [CrossRef]

101. Kovacs, M.; Nagy, M.; Borszéki, J.; Halmos, P. Indirect determination of fluoride in aqueous samples by inductively coupled plasma atomic emission spectrometry following precipitation of CeF3. J. Fluor. Chem. 2009, 130, 562-566. [CrossRef]

102. Parham, H.; Rahbar, N. Solid phase extraction-spectrophotometric determination of fluoride in water samples using magnetic iron oxide nanoparticles. Talanta 2009, 80, 664-669. [CrossRef] [PubMed]

103. Khalifa, M.E.; Hafez, M.A. Spectrophotometric and complexometric methods for the determination of thorium and fluoride using bromocresol orange reagent. Talanta 1998, 47, 547-559. [CrossRef]

104. Arancibia, J.A.; Rullo, A.; Olivieri, A.C.; Di Nezio, S.; Pistonesi, M.F.; Lista, A.; Band, B.S. Fast spectrophotometric determination of fluoride in ground waters by flow injection using partial least-squares calibration. Anal. Chim. Acta 2004, 512, 157-163. [CrossRef]

105. Marques, T.L.; Coelho, N.M. Proposed flow system for spectrophotometric determination of fluoride in natural waters. Talanta 2013, 105, 69-74. [CrossRef]

106. Zolgharnein, J.; Shahrjerdi, A.; Azimi, G.; Ghasemi, J. Spectrophotometric Determination of Trace Amounts of Fluoride Using an Al-Xylenol Orange Complex as a Colored Reagent. Anal. Sci. 2009, 25, 1249-1253. [CrossRef]

107. Faraj-Zadeh, M.A.; Kalhor, E.G. Extraction-Spectrophotometric Method for Determination of Fluoride in the Range of Microgram per Liter in Natural Waters. Microchim. Acta 2001, 137, 169-171. [CrossRef]

108. Barghouthi, Z.; Amereih, S. Spectrophotometric determination of fluoride in drinking water using aluminium complexes of triphenylmethane dyes. Water SA 2012, 38, 543-548. [CrossRef]

109. Barghouthi, Z.; Amereih, S. Field determination of fluoride in drinking water using a polymeric aluminium complex of 5-(2carboxyphenylazo)-8-hydroxyquinoline impregnated paper. Int. J. Environ. Anal. Chem. 2013, 93, 565-577. [CrossRef]

110. R̉užička, J.; Hansen, E. Flow injection analyses: Part I. A new concept of fast continuous flow analysis. Anal. Chim. Acta 1975, 78, 145-157. [CrossRef]

111. Tzanavaras, P.D.; Themelis, D.G. Review of recent applications of flow injection spectrophotometry to pharmaceutical analysis. Anal. Chim. Acta 2007, 588, 1-9. [CrossRef]

112. Farrell, J.R.; Iles, P.J.; Sands, T.J. Simultaneous determination of fluoride and phenolics in water using flow-injection analysis. Lab. Robot. Lab. Robot. Autom. 1999, 11, 105-109. [CrossRef]

113. Cardwell, T.; Cattrall, R.; Mitri, M. Gas diffusion with preconcentration for the determination of fluoride in water samples by flow injection. Talanta 1994, 41, 115-123. [CrossRef]

114. Garrido, M.; Lista, A.; Palomeque, M.; Fernandezband, B. Fluorimetric determination of fluoride in a flow assembly integrated on-line to an open/closed FIA system to remove interference by solid phase extraction. Talanta 2002, 58, 849-853. [CrossRef]

115. Pérez-Ruiz, T.; Martínez-Lozano, C.; Tomas, V.; Sanz, A. Flow injection spectrofluorimetric determination of fluoride or phosphate based on their inhibitory effect on the photo-oxidation of acridine catalysed by iron(III). Analyst 1996, 121, 477-481. [CrossRef]

116. Marco, V.; Carrillo, F.; Pérez-Conde, C.; Camara, C. Kinetic flow-injection spectrofluorimetric method for the determination of fluoride. Anal. Chim. Acta 1993, 283, 489-493. [CrossRef]

117. Manzoori, J.L.; Miyazaki, A. Indirect inductively coupled plasma atomic emission determination of fluoride in water samples by flow injection solvent extraction. Anal. Chem. 1990, 62, 2457-2460. [CrossRef]

118. Ruzicka, J.; Marshall, G.D. Sequential injection: A new concept for chemical sensors, process analysis and laboratory assays. Anal. Chim. Acta 1990, 237, 329-343. [CrossRef]

119. Economou, A.; Tzanavaras, P.; Themelis, D.G. Sequential-Injection Analysis: A Useful Tool for Clinical and Biochemical Analysis. Curr. Pharm. Anal. 2007, 3, 249-261. [CrossRef]

120. Chansaenpak, K.; Kamkaew, A.; Weeranantanapan, O.; Suttisintong, K.; Tumcharern, G. Coumarin Probe for Selective Detection of Fluoride Ions in Aqueous Solution and Its Bioimaging in Live Cells. Sensors 2018, 18, 2042. [CrossRef] 
121. Lin, Q.; Yang, Q.-P.; Sun, B.; Lou, J.-C.; Wei, T.-B.; Zhang, Y.-M. A highly selective and sensitive fluorescence "turn-on" fluoride ion sensor. RSC Adv. 2015, 5, 11786-11790. [CrossRef]

122. Mandal, N.; Mitra, S.; Bandyopadhyay, D. Paper-Sensors for Point-of-Care Monitoring of Drinking Water Quality. IEEE Sens. J. 2019, 19, 7936-7941. [CrossRef]

123. Wu, X.; Wang, H.; Yang, S.; Tian, H.; Liu, Y.; Sun, B. Highly Sensitive Ratiometric Fluorescent Paper Sensors for the Detection of Fluoride Ions. ACS Omega 2019, 4, 4918-4926. [CrossRef] [PubMed]

124. Mandal, T.K.; Hou, Y.; Gao, Z.; Ning, H.; Yang, W.; Gao, M. Graphene Oxide-Based Sensor for Ultrasensitive Visual Detection of Fluoride. Adv. Sci. 2016, 3, 1600217. [CrossRef] [PubMed]

125. Mukherjee, S.; Shah, M.; Chaudhari, K.; Jana, A.; Sudhakar, C.; Srikrishnarka, P.; Islam, R.; Philip, L.; Pradeep, T. Smartphonebased Fluoride-specific Sensor for Rapid and Affordable Colorimetric Detection and Precise Quantification at Sub-ppm Levels for Field Applications. ACS Omega 2020, 5, 25253-25263. [CrossRef]

126. Udhayakumari, D. Detection of toxic fluoride ion via chromogenic and fluorogenic sensing. A comprehensive review of the year 2015-2019. Spectrochim. Acta Part A Mol. Biomol. Spectrosc. 2020, 228, 117817. [CrossRef]

127. Sui, B.; Kim, B.; Zhang, Y.; Frazer, A.; Belfield, K.D. Highly Selective Fluorescence Turn-On Sensor for Fluoride Detection. ACS Appl. Mater. Interfaces 2013, 5, 2920-2923. [CrossRef]

128. Qiu, B.; Zeng, Y.; Cao, L.; Hu, R.; Zhang, X.; Yu, T.; Chen, J.; Yang, G.; Li, Y. A colorimetric and ratiometric fluorescence sensor for sensitive detection of fluoride ions in water and toothpaste. RSC Adv. 2016, 6, 49158-49163. [CrossRef]

129. Saikia, G.; Dwivedi, A.K.; Iyer, P.K. Development of solution, film and membrane based fluorescent sensor for the detection of fluoride anions from water. Anal. Methods 2012, 4, 3180-3186. [CrossRef]

130. Yamaguchi, S.; Akiyama, S.; Tamao, K. Colorimetric Fluoride Ion Sensing by Boron-Containing $\pi$-Electron Systems. J. Am. Chem. Soc. 2001, 123, 11372-11375. [CrossRef] [PubMed]

131. Yang, X.-F. Novel fluorogenic probe for fluoride ion based on the fluoride-induced cleavage of tert-butyldimethylsilyl ether. Spectrochim. Acta Part A Mol. Biomol. Spectrosc. 2007, 67, 321-326. [CrossRef]

132. Palacios, M.A.; Nishiyabu, R.; Marquez, M.; Anzenbacher, P. Supramolecular Chemistry Approach to the Design of a HighResolution Sensor Array for Multianion Detection in Water. J. Am. Chem. Soc. 2007, 129, 7538-7544. [CrossRef] [PubMed]

133. Aydogan, A.; Koca, A.; Şener, M.K.; Sessler, J.L. EDOT-Functionalized Calix[4]pyrrole for the Electrochemical Sensing of Fluoride in Water. Org. Lett. 2014, 16, 3764-3767. [CrossRef]

134. Hinterholzinger, F.M.; Rühle, B.; Wuttke, S.; Karaghiosoff, K.; Bein, T. Highly sensitive and selective fluoride detection in water through fluorophore release from a metal-organic framework. Sci. Rep. 2013, 3, 1-7. [CrossRef] 